\title{
A Non-colonial Power in Colonial and Postcolonial Africa
}

The connections between Switzerland and Africa are not immediately obvious. After all, this small, land-locked European country has never had colonies abroad. Nevertheless, there were and are numerous ties between Swiss and African people, organisations, and states. In the eighteenth and nineteenth centuries, some Swiss citizens and companies were involved in the triangular slave trade. ${ }^{1}$ In the wake of the European powers, which extended their control over the continent during the last third of the nineteenth century, Swiss missionaries, farmers, and entrepreneurs settled in Africa, benefiting from the structures put in place by the colonial authorities. ${ }^{2}$ Swiss geographical societies launched expeditions to Africa. ${ }^{3}$ Back in Switzerland, missionaries and explorers contributed to the dissemination of colonial imageries and racial

1 Thomas David, Bouda Etemad, Janick Marina Schaufelbuehl, La Suisse et l'esclavage des Noirs, Lausanne: Antipodes, 2005; Thomas David, Janick Marina Schaufelbuehl, "Swiss Conservatives and the Struggle for the Abolition of Slavery at the End of the Nineteenth Century", Itinerario 34:2 (2010), pp. 87-103; Hans Fässler, Reise in schwarz-weiss: Schweizer Ortstermine in Sachen Sklaverei, Zürich: Rotpunktverlag, 2005; Konrad J. Kuhn, Béatrice Ziegler, "Die Schweiz und die Sklaverei: Zum Spannungsfeld zwischen Geschichtspolitik und Wissenschaft", Traverse 16:1 (2009), pp. 116-130; Niklaus Stettler, Peter Haenger, Robert Labhardt, Baumwolle, Sklaven und Kredite: die Basler Welthandelsfirma Christoph Burckhardt \& Cie. In revolutionärer Zeit (1789-1815), Basel: Merian, 2004.

2 See notably Hans Werner Debrunner, Schweizer im kolonialen Afrika, Basel: Basler Afrika Bibliographien, 1991; Andrea Franc, Wie die Schweiz zur Schokolade kam: Der Kakaohandel der Basler Handelsgesellschaft mit der Kolonie Goldküste (1893-1960), Basel: Schwabe, 20o8; Mathieu Humbert, "L'expansionnisme suisse en Afrique sub-saharienne au cours du XIXe siècle. Un aperçu", Schweizerische Gesellschaft für Wirtschafts- und Sozialgeschichte/Société suisse d'histoire économique et sociale 29 (2015), pp. 145-161; René Lenzin, 'Afrika macht oder bricht einen Mann': Soziales Verhalten und politische Einschätzung einer Kolonialgesellschaft am Beispiel der Schweizer in Ghana (1945-1966), Basel: Basler Afrika Bibliographien, 1999; René Lenzin, "Schweizer im kolonialen und postkolonialen Afrika. Statistische Übersicht und zwei Fallbeispiele", Studien und Quellen 28 (2002), pp. 299-326; Claude Lützelschwab, La Compagnie Genevoise des Colonies Suisses de Sétif (1853-1956): Un cas de colonisation privée en Algérie, Bern: Lang, 2006.

3 Ruth Hagen, Expeditionen in den dunklen Kontinent: Die geografischen Gesellschaften der Schweiz und die wissenschaftliche Erforschung Afrikas, Saarbrücken: VDM, 20o9; Fabio Rossinelli, "Sociétés de géographie et impérialisme suisse au 19e siècle. Un tour d'horizon et deux exemples représentatifs", Schweizerische Zeitschrift für Geschichte 67:1 (2017), pp. 1-19. 
stereotypes. ${ }^{4}$ The gaining of independence by the formerly colonised territories and the departure of the European colonial powers, which started in the late 195os, coincided and interacted with the global East-West conflict. For that reason, and due to the existence of multiple Swiss-African entanglements, Swiss foreign policymakers observed the decolonisation of sub-Saharan Africa with great interest.

In 1957, Ghana was the first state in sub-Saharan Africa to gain independence from the UK. Three years later, in the 'Year of Africa' 1960, no less than 17 African states joined the UN. ${ }^{5}$ As the majority of the former British, French, and Belgian colonies gained independence in the late 1950s and early 196os in a predominantly peaceful process, the Swiss government adopted a low profile. It was careful not to be associated with the colonial powers and tried to maintain good relations with all parties in order to keep out of potential conflicts linked to decolonisation. Swiss foreign policymakers and business leaders hoped that the departure of the European colonial powers would result in increased export and investment opportunities for Swiss business, which would in turn contribute to Africa's economic development. The Swiss government therefore made efforts to establish cordial relations with the new African leaders, notably through the instrument of development aid, which was also intended to help counteract Communist influence in the Third World. Swiss diplomats believed that Switzerland was a particularly valued partner for independent African countries, as this small Western European neutral state with its reputation as a humanitarian actor was tainted neither by a past as a colonial power nor by adherence to one of the big geopolitical blocs. ${ }^{6}$ During the two major violent decolonisation conflicts in the early 196os-the Congo crisis and the independence war in Algeria-Bern played a more active role. Between 1960 and 1963, Switzerland participated in the UN peacekeeping mission in the former Belgian Congo by conducting supply and transport flights and by seconding Swiss experts to the mission. ${ }^{7}$ From 1960, Switzerland provided its good offices during the negotiations between France and the Algerian Front

4 Patrick Minder, La Suisse coloniale. Les représentations de l'Afrique et des Africains en Suisse au temps des colonies (1880-1939) Bern: Peter Lang, 2011.

5 United Nations (UN), "Growth in United Nations membership", https://www.un.org/en/ about-us/growth-in-un-membership (11 August 2021).

6 Marc Perrenoud, "Guerres, indépendances, neutralité et opportunités: quelques jalons historiques pour l'analyse des relations économiques de la Suisse avec l'Afrique (des années 1920 aux années 1960)", in Bott et al., Suisse - Afrique, pp. 85-104.

7 See Marisa Birri, Die Schweiz und der Kongo in den ersten Jahren der Unabhängigkeit 196o1963, unpublished Master thesis, University of Bern, 2007; Birri, "Der Kalte Krieg war in Afrika ein Heisser". 
de Libération Nationale (National Liberation Front, FLN), which culminated in the Evian Accords of March 1962 that confirmed Algeria's independence. ${ }^{8}$ In $1965,6,500$ Swiss nationals were recorded as living in sub-Saharan Africa, with a further 4,300 in South Africa. ${ }^{9}$

The foundation of the OAU in 1963 was a sign that African states intended to play a major role in the international arena and that they would not tolerate the Swiss government's complacent attitude towards colonialism and white minority rule forever. According to its charter, which was signed by 30 heads of state on 25 May 1963, as an organisation of independent African countries, the OAU aimed to promote African self-determination and cooperation between its member states and adhered to a policy of non-alignment in the Cold War. The liberation of the remaining territories under colonial rule was one of the main issues discussed at the OAu's founding conference in Addis Ababa. African leaders agreed to materially support liberation movements and exert diplomatic pressure on the colonial powers to induce them to grant their colonies independence. For this purpose, they set up a committee of nine members to coordinate aid for the liberation movements, the Coordinating Committee for the Liberation of Africa or Liberation Committee, with headquarters in Dar es Salaam. The OAU focused its activities on Portugal, the last European colonial power to resist decolonisation, and Apartheid South Africa. ${ }^{10}$

The institutionalisation of Switzerland's development cooperation policy was intricately linked to the decolonisation of Africa. In the context of the global East-West confrontation, both the Eastern and Western blocs used foreign aid as a tool in their competition for the Third World. Each side prescribed its own model of how states in the global South might be lifted out of poverty. The Swiss government's commitment to humanitarian aid and development cooperation is expressed in the principle of solidarity, and has thus formed an integral part of Switzerland's neutrality policy since the end of the Second World War. Federal Councillor Max Petitpierre, head of the FPD between 1945 and 1961, introduced the notion of 'neutrality and solidarity' in order to improve the image of Swiss neutrality—which had suffered due to its economic and financial relations with the axis powers-by underlining the

8 See Damien Carron, La Suisse et la guerre d'indépendance algérienne (1954-1962), Lausanne: Éditions Antipodes, 2013, pp. 373-419.

$9 \quad$ Lenzin, "Schweizer im kolonialen und postkolonialen Afrika", pp. 302-303.

10 C. O. C. Amate, Inside the OAU. Pan-Africanism in Practice, New York: St. Martin's Press, 1986, pp. 58-64, 211-214. More recent works on the OAU include Klaas van Walraven, Dreams of Power. The Role of the Organization of African Unity in the Politics of Africa, 1963-1993, Aldershot: Ashgate Publishing, 1999; Gaston-Jonas Kouvibidila, Histoire de la construction de l'Afrique, Paris: L'Harmattan, 2011. 
country's willingness to help face the political and economic challenges of the early Cold War. ${ }^{11}$ The Swiss government's solidarity policy initially focused on Europe, where it contributed to the Marshall Plan in aid of the reconstruction of Europe. The provision of Swiss aid to the Third World started in 1949-1950. The Federal Council decided to participate in the Expanded Programme of Technical Assistance, later the UN Development Programme (UNDP), launched by the UN on the proposal of US President Harry S. Truman. In the 195os, Swiss official aid consisted mainly of contributions to multilateral aid programmes, support for private Swiss charities, expert missions, and scholarships for foreign students. ${ }^{12}$

Between 1959 and 1961, when many sub-Saharan African states achieved their independence, the Swiss government's development aid policy was reorganised and its budget increased. In 1961, the Federal Council created the STC within the FPD, headed by the Delegate for Technical Cooperation. The term 'technical cooperation', used since 1961 instead of 'technical aid, ${ }_{1}^{13}$ underlines the supposedly apolitical character of Swiss development cooperation with the Third World. Yet, from its inception, Switzerland's development policy was politically motivated. On the one hand, it was aimed at containing Communist influence in the Third World. ${ }^{14}$ On the other hand, there was a merging of development cooperation and the promotion of Swiss exports. ${ }^{15}$ Within the FPD, the STC was responsible for Switzerland's bilateral development aid. Humanitarian aid and multilateral assistance were primarily the domain of the DIo. The Trade Division was in charge of different resources for aid for trade, such as capital exports, export risk guarantees (ERG), and financial agreements. The

11 Trachsler, Bundesrat Max Petitpierre, pp. 98-99, 110-115.

12 Daniele Waldburger, Lukas Zürcher, Urs Scheidegger, 'Im Dienst der Menschheit'. Meilensteine der Schweizer Entwicklungszusammenarbeit seit 1945, Bern: Haupt, 2012, pp. 20-30; René Holenstein, Wer langsam geht, kommt weit. Ein halbes Jahrhundert Schweizer Entwicklungshilfe, Zürich: Chronos, 2010, pp. 48-49.

13 See Marc Perrenoud, "Les relations de la Suisse avec l'Afrique lors de la décolonisation et des débuts de la coopération au développement", Revue internationale de politique de développement, 1 (2010), pp. 81-98, p. 88.

14 Daniel Trachsler, "Neutralität, Solidarität und Kalter Krieg: Die Entwicklungshilfe als aussenpolitisches Instrument in der Ära Petitpierre, 1945-1961" in Sara Elmer, Konrad J. Kuhn, Daniel Speich Chassé, Itinera. Handlungsfeld Entwicklung. Schweizer Erwartungen und Erfahrungen in der Geschichte der Entwicklungszusammenarbeit/Le champ d'action "développement". Attentes et expériences suisses dans le travail de développement, Basel: Schwabe, 2014, pp. 167-183.

15 Roger Graber, Entwicklungshilfe und Exportförderung im Kalten Krieg: Interessen, Motive und Strategien der Schweizer Exportindustrie in Entwicklungsländern (1955-1965), unpublished Master thesis, University of Zurich, 20o6. See also the contributions in Peter Hug, Beatrix Mesmer (eds.), Von der Entwicklungshilfe zur Entwicklungspolitik, Bern: SFA, 1993. 
division of competences was not always clear. In the 196os, bilateral project aid guided and financed by the STC was frequently executed by non-governmental organisations (NGO). According to guidelines established in 1964, development cooperation was subject to the approval of the receiving state and the bulk of aid was to be focused on a few key countries. The selection of these countries was somewhat arbitrary and based on ideological criteria, the presence of Swiss settlers or charities, or perceived similarities with Switzerland. ${ }^{16}$

Until the mid-196os, the Swiss government's development policy enjoyed broad domestic acceptance. This changed towards the end of the decade. With some delay, Swiss churches and solidarity groups took up the criticism of unequal North-South relations that had been issued by Third World governments a few years previously and demanded, in particular, the disconnection of aid from economic interests. Right-wing circles insisted that Swiss taxpayers' money should not be spent abroad and opposed the solidarity movement's demands for an increase in Switzerland's aid budget. Due to the growing politicisation of development cooperation, it took five years for a law on humanitarian aid and development cooperation to be adopted, in March 1976. ${ }^{17}$ The intense domestic debates surrounding Switzerland's development cooperation policy and the multitude of state and private actors involved in its implementation - charities, missionary societies, economic leaders - meant that the Swiss government's freedom of action in the field of aid was, to some extent, restricted.

Despite government efforts to increase Switzerland's commitment to development aid, the latter remained notoriously limited. In a comparative analysis of the aid policies of Austria, Denmark, Finland, Norway, Sweden, and Switzerland, economist Jacques Forster observed the emergence of two groups. Denmark, Sweden and Norway strongly increased their disbursements for development cooperation in the 1970s and exceeded the OECD target of $0.7 \%$ of gross national product at the end of the decade. The commitment of Austria, Finland and Switzerland hovered around $0.2 \%$ in 1979. In 1978, the Swedish government spent nearly 4.5 times as much as its Swiss counterpart on aid to the Third World. ${ }^{18}$ For this reason, some contemporaries criticised Switzerland

16 Waldburger, Zürcher, Scheidegger, 'Im Dienst der Menschheit', pp. 47-55. See also Zürcher, "So fanden wir auf der Karte diesen kleinen Staat".

17 See Samuel Misteli, "Der UnCTAD-Moment. Die Entstehung des Nord-Süd-Konflikts und die Politisierung des Schweizer Entwicklungsdiskurses”, in Elmer, Kuhn, Speich Chassé, Handlungsfeld Entwicklung, pp. 185-211; Holenstein, Wer langsam geht, pp. 62-66. 
for not pulling its weight in the global South. Commenting on the disconnect between Switzerland's economic and financial strength and its unimpressive public foreign aid record, the US ambassador in Bern suggested in 1968 that Switzerland should be encouraged to "compare its performance with that of the 'big countries' rather than to let the Swiss indulge in their propensity for small-country thinking." 19

How do Switzerland's relations with Angola, Mozambique, Ethiopia, and Somalia fit the foreign policy pattern just sketched out? While Somalia was one of many states to achieve independence in 196o, the other three countries occupied exceptional positions during the decolonisation of sub-Saharan Africa. Ethiopia has never been colonised, whereas Angola and Mozambique were among the last colonies on the African continent because the authoritarian Portuguese government refused decolonisation until the mid-197os. This chapter first gives an overview of Switzerland's political and humanitarian relations with the four African countries under consideration prior to the regime changes, or, in the case of the Portuguese colonies, before the intensification of the national and international debate surrounding white minority rule in the late 196os. Secondly, it focuses on the development of commercial exchanges with and investments in the four countries and determines their relative importance compared to the whole continent. This reveals the overwhelming significance of Switzerland's political, economic, and financial interests in Apartheid South Africa to its foreign policy on the continent.

Four (Un-)Exceptional Cases: Relations with Angola, Mozambique, Ethiopia and Somalia

Somalia is the only one of the four selected African countries whose relations with Switzerland developed in line with the Swiss government's established policy during decolonisation. However, it held very little interest for Switzerland's political and economic elites and bilateral relations were extremely low-key. Scholars of Somali history underline the homogeneity of its population and culture and the strong nationalism of its people, which would determine its post-independence history. This clan-based, Muslim society of mostly pastoral nomads established trading cities on the coast of the Gulf of Aden

19 Airgram from John S. Hayes, US ambassador in Switzerland, to the Department of State, "Aid Club of Small Countries", 19.03.1968, p. 2, National Archives and Record Administration, College Park, Maryland, USA (NARA), Record Group (RG) 59, Subject-Numeric Files 1967-1969, AID (sWITZ), box 45o. 
and the Indian Ocean. In the second half of the nineteenth century, Britain, France, and Italy began to increase their control over the coast of the Horn of Africa, competing for colonial influence. At the same time, the Ethiopian Empire expanded its territory to include the Somali-inhabited Ogaden region in the hinterland. By 1897, a series of treaties completed Somalia's partition. French Somaliland (from 1967, French Territory of the Afars and Issas, Djibouti after independence in 1977) was bordered by the British Somaliland Protectorate on the Gulf of Aden. In the South, on the coast of the Indian Ocean, Italy established a colony. Until its defeat in 1920, the religious Derwish movement headed pan-Somali resistance against colonial domination. Somali territories were briefly unified by the Second World War. In August 1940, the Italian army captured British Somaliland, having already occupied Ethiopia, including the Ogaden, in 1936. In early 1941, the British reoccupied northern Somalia. They continued on and took control of Ethiopia for the Ethiopian Emperor as well as Italian Somaliland. For almost a decade, the Ogaden as well as British and Italian Somaliland were under British military administration. In this period, Somali nationalism grew. Among a number of Somali associations and movements, the Somali Youth Club opened in Mogadishu in May 1943. Later renamed the Somali Youth League (SYL), it turned into a political party that aimed to unite all Somalis and educate the youth. Although it was unable to prevent the UNGA 1949 decision to return Italian Somaliland to Italy for ten years as a UN trusteeship or the return of the Ogaden to Ethiopia that was completed in 1954, the SYL was instrumental in leading British and Italian Somaliland to independence and union. On 1 July 196o, the Republic of Somalia was created as a liberal democracy. While the SYL remained the most powerful political party, a multitude of other political parties echoed clan divisions and increased political fragmentation. The difficulties of incorporating the former British and Italian territories, with their different administrative structures and colonial languages, into a single state also contributed to this. ${ }^{20}$

After Somalia's independence, the Swiss Federal Council recognised the new state and sent the head of the DIO to attend the independence ceremonies in Mogadishu. ${ }^{21}$ As economic exchange between the two states was virtually nonexistent and only seven Swiss nationals lived in Somalia, the establishment of

20 For useful introductions to Somali history, see David D. Laitin, Said S. Samatar, Somalia. Nation in Search of a State, Boulder:Westview Press, 1987; Ioan M. Lewis, A Modern History of the Somali. Nation and State in the Horn of Africa, Oxford: James Currey, 4th edition, 2002.

21 Max Petitpierre, Federal Councillor and head of the FPD, proposal to the Federal Council, "Cérémonies d'indépendance de la Somalia. Nomination de M. le Ministre Jean de Rham, Chef de la Division des organisations internationales, en qualité d'Ambassadeur 
a diplomatic representation in this state was not considered a priority. ${ }^{22}$ From independence, Somalia's foreign policy was driven by the will to unite, under one banner, ethnic Somalis who were living in French Somaliland, Kenya's Northern Frontier District, and the Ethiopian Ogaden region. This led to tensions and armed conflicts with Somalia's neighbouring states. ${ }^{23}$ Therefore, the FPD's Administration Division (AD) decided in July 1967 to accredit the Swiss ambassador in Egypt to Somalia. ${ }^{24}$ A year later, Switzerland and Somalia finally established diplomatic relations. In November 1968, a consular agency under the guidance of Swiss businessman Robert Camenzind was opened in Mogadishu. ${ }^{25}$ Swiss development aid provided to Somalia was very limited and amounted to a total of CHF 270,00o for the period from 1961 to early $1967 .{ }^{26}$ The 1969 coup d'état by General Mohammad Siad Barre, who instituted a military regime and concluded a friendship treaty with the Soviet Union in July 1974, therefore had little impact on Swiss interests.

In Ethiopia, the situation was different. The history of modern Ethiopia is said to have begun with the coronation of Emperor Tewodros in 1855 . He started a process of unification and centralisation in the Horn of Africa by bringing a series of principalities and territories under the control of this multi-ethnic state headed by a Christian elite. Ethiopia's territorial expansion continued against the backdrop of European colonialist designs on the region. Emperor Menelik's 1896 victory against an invading Italian army at Adwa confirmed Ethiopia's independence. In a succession of treaties, the European colonial powers subsequently recognised Ethiopia's frontiers and the African state joined the League of Nations in $1922 .{ }^{27}$ Swiss contacts with the Ethiopian Empire date back to the arrival of the first Swiss missionaries in Ethiopia in the early nineteenth century. For 30 years from 1878 , Swiss engineer and railway pioneer Alfred Ilg acted as advisor to the Ethiopian court. These bilateral ties intensified in the twentieth century. In May 1933, Bern signed a Friendship and

extraordinaire en mission spéciale et Chef de la délégation suisse", 16.06.196o, SFA E2001E\#1980/83\#4044*.

22 Note from Raymond Probst, FPD, to Jean de Rham, head of the DIO, "Somalia", 15.06.196o, SFA E2OO1E\#1980/83\#4044*.

23 Laitin, Samatar, Somalia, pp. 129-138; Lewis, A Modern History of the Somali, pp. 178-195.

24 Letter from Fred Bieri, AD, to André Parodi, Swiss ambassador in Egypt, "Republik von Somalia", 12.07.1967, SFA E2004B\#199o/219\#615*.

25 Information and Press Service of the FPD, press release, "Aufnahme diplomatischer Beziehungen", 24.07.1968, SFA E2001E\#1980/83\#4044*; Ch. Glauser, AD, notice, "Agence consulaire de Suisse à Mogadiscio (Somalie)", 11.11.1968, sFA E2004B\#199o/219\#615*.

26 Letter from Jacques Rial, STC, to the Swiss embassy in Egypt, 25.07.1967, SFA E2005A\#1980/82\#798*.

27 See Bahru Zewde, $A$ History of Modern Ethiopia. 
Trade Treaty with the government of Emperor Haile Selassie, who came into power in 1930. Swiss firms like the arms manufacturers Oerlikon Bührle and Schweizerische Industriegesellschaft Neuhausen (SIG) established trade relations with Ethiopia. Between 1934 and 1936, industrialist Emil Bührle acted as Ethiopia's honorary consul in Zurich. ${ }^{28}$

The Italo-Ethiopian War of $1935^{-1936}$ and the subsequent Italian occupation of Ethiopia cast a shadow over these developing relations. On 3 October 1935, the Mussolini regime attacked Ethiopia, its fellow member of the League of Nations. As this constituted a breach of the League's Covenant, the organisation's General Assembly imposed sanctions on the attacker. The Swiss government, which had joined the League of Nations in 1920 after the organisation specifically acknowledged Switzerland's neutral status, voted with the majority. However, Bern's subsequent actions revealed its solidarity with its southern neighbour, with which it had very close cultural, economic, and political links. Keen to preserve cordial relations with Mussolini's fascist regime, and considering Ethiopia to be a backward, underdeveloped country with a government lacking state control, the Swiss authorities watered down the sanctions. They limited trade with Italy to the pre-attack level instead of interrupting it, and extended the embargo on arms exports to Ethiopia as well as its attacker. This position was criticised by other League members and damaged Switzerland's image within the organisation. When the Italo-Ethiopian War ended in May 1936 with the occupation of Addis Ababa, the Swiss authorities supported the early lifting of sanctions against Italy, refused permission to the Ethiopian emperor to live in his villa at Lake Geneva, and, in December 1936, formally recognised Italian sovereignty over Ethiopia. ${ }^{29}$

The end of the Second World War saw an important territorial reorganisation in the Horn of Africa, which would cause bitter struggles in the coming decades. In late 1941, British and Ethiopian troops liberated Ethiopia. In 1950, the UNGA joined together the former Italian colony of Eritrea in a federation with

28 Christoph Graf, "Die Schweiz und die Dritte Welt. Die Anerkennungspraxis und Beziehungsaufnahme der Schweiz gegenüber dekolonisierten aussereuropäischen Staaten sowie die Anfänge der schweizerischen Entwicklungshilfe nach 1945", Studien und Quellen 12 (1986), pp. 37-112, pp. 44-47; Marc Perrenoud, "Ethiopie", 15.10.2001, Historical Dictionary of Switzerland (HLS) Online, http://www.hls-dhs-dss.ch (13 January 2021); Beat de Fischer, Contributions à la connaissance des relations suisses-égyptiennes (d'environ 100 à 1949) suivies d'une esquisse des relations suisses-éthiopiennes (jusqu'en 1952), Lisbon: Ramos, Afonso \& Moita, Ltd, 1956, pp. 281-302.

29 See Neville Wylie, Marco Wyss, "Neutrality 'de jour': Switzerland and the Italo-Abyssinian War of 1935-6" in Frank McDonough (ed.), The Origins of the Second World War. An International Perspective, London: Continuum, 2011, pp. 278-293; Rainer Baudendistel, Between Bombs and Good Intentions. The Red Cross and the Italo-Ethiopian War, 1935-1936, New York: Berghahn Books, 2006, pp. 7-15. 
Ethiopia. The Ogaden area in the east of Ethiopia, which had been annexed by the UK during the War, was restored to Ethiopia in 1954. From the early 1950s onwards, US influence in Ethiopia increased. In 1953, the two states signed military agreements that guaranteed US access to Ethiopian military installations, notably the Kagnew base at Asmara, Eritrea, in exchange for extensive military assistance. The US also played an important role in the development of infrastructure and in education. ${ }^{30}$ Swiss-Ethiopian relations normalised soon after the Second World War. In June 1952, the Swiss Parliament agreed to the opening of a Swiss diplomatic representation in Addis Ababa. In November 1954, Haile Selassie made a state visit to Switzerland, which garnered much interest from the press and the Swiss population. ${ }^{31}$ After this visit, political relations between the two states deepened, although they were mostly focused on the person of the Emperor, who travelled regularly to Geneva and Lausanne. In 1970, 130 Swiss citizens lived in Ethiopia, working in business capacities, as employees of international organisations and aid projects, or as teachers, or missionaries. ${ }^{32}$ Since Addis Ababa hosted the headquarters of the OAU and offices of several international organisations, Heinz Langenbacher, Swiss ambassador to Ethiopia in the early 1970s, frequently underlined the city's importance as an international capital_-“'Africa's Geneva". ${ }^{33}$

In the 196os, Switzerland's development cooperation with Ethiopia, one of Africa's poorest states, was sparse. The sTC supported only a single project: the construction of a commercial college in Dire Dawa that was inaugurated in November 1967 and managed by the Swiss branch of an order of Franciscan nuns. ${ }^{34}$ Between 1961 and 1971, Switzerland's total aid to Ethiopia, including

30 Bahru Zewde, A History of Modern Ethiopia, pp. 179-189; Paul B. Henze, Layers of Time. A History of Ethiopia, London: Hurst \& Company, 200o, pp. 235-248. For Ethiopia's military relationship with the US until the 1970s, see Jeffrey A. Lefebvre, Arms for the Horn. U.S. Security Policy in Ethiopia and Somalia 1953-1991, Pittsburgh: University of Pittsburgh Press, 1991, pp. 55-172.

$31 \quad$ Graf, "Die Schweiz und die Dritte Welt", pp. 46-55; letter from Etienne Dennery, French ambassador in Switzerland, to the French foreign minister, "Visite du Négus en Suisse", 23.11.1954, Centre des Archives diplomatiques, Nantes, France (CADN) 89PO/2002021/424. Letter from Fernand Bernoulli, Swiss Ambassador in Ethiopia, to the AD, "Schlussbericht des Missionschefs von Addis Abeba”, confidential, 07.07.1970, pp. 1-5, 8, Diplomatic Documents of Switzerland 1848-1975 (Dodis) Online, https://www.dodis.ch/en (13 January 2021), dodis.ch/37162.

33 Scherer, Durch die tiefsten Tiefen des Wellentals, p. 120.

34 Note from Sigismond Marcuard, Delegate for Technical Cooperation, to Heinz Langenbacher, Swiss ambassador in Ethiopia, "Projets de coopération technique en Afrique", 13.08.1970, SFA E2OO5\#1983/8\#169*; note from Serge François Salvi, STC, to Anne de Riedmatten, DIO, "Note concernant l'Ecole 'Notre Dame' à Dire-Dawa, Ethiopie", 16.o9.1970, SFA E2005\#1983/8\#170*. 
scholarships, support for missionaries, and food aid, amounted to approximately CHF 1.6 million. This corresponds to $0.9 \%$ of the STC's framework budget of $\mathrm{CHF} 180$ million for 1970-1972. ${ }^{35}$

In the early 1970s, the Swiss government engaged in one of its most considerable aid projects in Africa at that time; the financing and partial running of the Duke of Harar Memorial Hospital in Addis Ababa. Designed to serve as a university hospital with 5 oo beds, it was built by a Yugoslav firm, financed by an Ethiopian foundation, and handed over to the Ethiopian government in $1971{ }^{36}$ Unable to finance the equipment and running of the hospital, the Ethiopian government asked the governments of the US, USSR, UK, FRG, the Scandinavian countries, and Yugoslavia to step in. While the governments contacted agreed that the construction of such a large hospital had been a mistake and the local representative of the World Health Organization (wHO) expressed his scepticism, the project aroused the interest of the medical faculty of the university hospital in Bern. Professor Maurice Müller, head of the faculty's orthopaedic department, who had briefly directed a hospital in Ethiopia in the 1940 and was a personal friend of Federal Councillor Nello Celio of the FDF, played a key role in persuading the Swiss government to take on the project. ${ }^{37}$ Thanks to this personal connection, the FDF was involved in the early stages. On 12 October 1971, Nello Celio accepted a letter from Haile Selassie, asking Switzerland to equip and take over the running of the hospital for three years. Ten days later, a delegation of hospital specialists accompanied by the ViceDirector of the FDF's Financial Administration travelled to Addis Ababa. The delegation considered the takeover of the hospital to be a great opportunity, highlighting in particular the chance to foster goodwill in Africa's capital and the possibility of strengthening the position of Switzerland's pharmaceutical industry in Ethiopia. ${ }^{38}$

35 Pierre Graber, Federal Councillor and head of the FPD, proposal to the Federal Council, "Technische Zusammenarbeit und humanitäre Hilfe mit Aethiopien. Teileröffnung des Duke of Harar-Spitals in Addis Abeba", 29.03.1973, pp. 2-3, SFA E2001E-o1\#1987/78\#2799*; Swiss Federal Council, Bericht des Bundesrates an die Bundesversammlung über seine Geschäftsführung im Jahre 1971, 23.02.1972, p. 35.

36 Pierre Graber, proposal to the Federal Council, "Technische Zusammenarbeit und humanitäre Hilfe mit Aethiopien. Teileröffnung des Duke of Harar-Spitals in Addis Abeba", 29.03.1973, p. 6, SFA E2OO1E-o1\#1987/78\#2799*.

Letter from Heinz Langenbacher to the sTc, "Prinz Makonnen-Spital, Addis Abeba", 11.10.1971, pp. 1-2, SFA E610oB-o2\#1986/168\#1720*; note from AL to René Keller, chief of DIO, "Prinz Makonnen-Spital in Addis-Abeba", 19.10.1971, ibid.

38 Note from Bernhard Müller, Vice-Director of the Financial Administration of the FDF, to Nello Celio, Federal Councillor and head of the FDF, "Duke of Harar Memorial Hospital Addis Abeba; Besichtigungsreise vom 20. bis 24. Oktober 1971”, o3.11.1971, SFA 
The STC, however, considered the project to be too ambitious and too expensive, arguing that only multilateral action could ensure the running of the hospital in the years to come. ${ }^{39}$ Although the majority of FPD leaders opposed the takeover of the Duke of Harar Hospital, Celio and Professor Müller informed the Ethiopian government that Switzerland would step in. The FPD was left in the dark and, in May 1972, presented with a fait accompli. ${ }^{40}$ Due to Switzerland's limited budget for foreign aid, the proposal submitted to the Swiss Federal Council in March 1973 was substantially reduced. The FPD suggested a partial opening of the hospital under Swiss direction. With a capacity of 150 beds and a polyclinic able to treat up to 300 patients a day, the hospital was to focus on the teaching and formation of Ethiopian health staff. The salaries of the 40 Swiss personnel were to be paid by the Swiss authorities, while the Ethiopian government assured the remuneration of the 15 othiopian employees. After three years, the running of the hospital was to be handed over to the Ethiopian counterparts. Switzerland's contribution to the project amounted to CHF 8 million, 2 million of which were to be covered by the medical faculty of the University of Bern, which was also responsible for managing the project. ${ }^{41}$

On 3 November 1973, Haile Selassie officially opened the Duke of Harar Memorial Hospital in the presence of many Ethiopian government members, the diplomatic corps, representatives of international organisations, and the press. Ambassador Langenbacher was optimistic about the project's success and professed himself happy "to have received, with this development project, a political instrument, which should considerably facilitate my work in other areas." ${ }^{22}$ Little did he know that within a year, during the Ethiopian Revolution,

E610oB-o2\#1986/168\#1720*; Prof. Maurice Müller, head of the orthopaedic department of the university hospital in Bern, Prof. Rudolf Preisig, dean of the medical faculty of the university of Bern, F. Althaus, head of technical services of the university hospital in Bern, Jakob Itten, architect, Walter Mamie, executive director of the Tiefenau hospital in Bern, report, "Duke of Harar Memorial Hospital Addis Abeba. Bericht der Informationsreise", 10.12.1971, pp. 1, 29, SFA E2001E-o1\#1987/78\#2799*.

39 Letter from Sigismond Marcuard to Maurice Müller, 18.11.1971, SFA E610oB-o2\#1986/ $168 \# 1720^{*}$.

40 Note from Bernhard Müller to the stc, "Prinz Makonnen-Spital Addis Abeba", 12.05.1972, SFA E2001E-o1\#1987/78\#2799*; letter from Heinz Langenbacher to the STC, "Prinz Makonnen-Spital Addis Abeba”, 27.04.1972, ibid.; note from Bernhard Müller to Nello Celio, "Prinz-Makonnen Spital Addis Abeba", o1.05.1972, SFA E610oB-o2\#1986/168\#1720*.

Pierre Graber, proposal to the Federal Council, "Technische Zusammenarbeit und humanitäre Hilfe mit Aethiopien. Teileröffnung des Duke of Harar-Spitals in Addis Abeba", 29.03.1973, pp. 8-14, SFA E2001E-o1\#1987/78\#2799*.

42 Letter from Heinz Langenbacher to Pierre Graber, "Eröffnung des 'Duke of Harrar Memorial Hospital', Addis Abeba”, o5.11.1973, p. 2, SFA E2001E-o1\#1987/78\#2799*. 
the hospital would become a liability. In early 1974, civil and military protest against Haile Selassie's autocratic regime escalated. After months of political turmoil, the Emperor was forced to step down in September 1974 and the military government that assumed power would subsequently turn towards the USSR.

With the exception of some internal disagreements about the Swiss engagement in the Duke of Harar project, Switzerland's bilateral relations with independent Somalia and Ethiopia were largely uncontroversial before the regime changes. As Angola and Mozambique remained under colonial rule and experienced violent independence wars, and African leaders and Swiss civil society actors strongly criticised white minority rule in Southern Africa from the late 196 os onwards, Switzerland's role in these two states was more contentious. Bern's political course, which would remain in place until Mozambique and Angola became independent in 1975, was set during the early phase of the independence wars, which started with the uprising of Angolan nationalists in 1961. At that time, Swiss foreign policymakers saw no need to deviate from their tried and tested low-key attitude and adopted a wait-and-see approach. The approach can be summed up as keeping the door open to both the colonisers and the colonised, while avoiding taking an official position. The Swiss government was careful to remain on good terms with Lisbon, its fellow member of the European Free Trade Association (EFTA), while not antagonising nationalist leaders that might later become part of independent African governments.

Portugal's presence in Africa dates back to the sixteenth century, when it established supply points on the sea routes to Asia on the islands of Cape Verde and São Tomé e Príncipe and on the coasts of Guinea-Bissau, Angola, and Mozambique. In the seventeenth and eighteenth centuries, its presence was motivated by the Atlantic slave trade. Angolans, in particular, were enslaved and transported to the plantations in the Portuguese colony of Brazil. Following Brazil's independence, in 1822, and the abolition of the slave trade, Portugal exercised scant control over its few coastal possessions in Africa. During the European imperial powers' 'scramble for Africa' in the late nineteenth century, Portugal started to extend its political, military, and economic control over its colonies. In Mozambique, concession companies that operated sugar and cotton plantations with foreign capital initially played an important role in the administration of the territory. In Angola, rubber and later cotton and coffee plantations were established. It was not until 1926 that forced labour was abolished in Portuguese Africa. Under the authoritarian Estado Novo regime in Portugal, which came into power in 1933, the administration of the colonies 
was further centralised. Compared to other African regions, anti-colonial protest was slow to emerge and was poorly coordinated until the 195 os. $^{43}$

In the early 1950s, Angolan nationalists started to manifest their discontent with Portugal's colonial rule and formed a variety of political groups to promote self-determination. Two rival movements each claimed to have started the armed uprising in Angola: the multiracial MPLA that was based in the area of the capital, Luanda, and included members of the Angolan Communist party, and the União dos Povos de Angola (Union of the Peoples of Angola, UPA). The UPA, which would become the Frente Nacional para a Libertação de Angola (National Front for the Liberation of Angola, FNLA) in 1962, was based on the common ethnic background of its members and had its strongholds in the north of Angola. Its leader, Holden Roberto, had close links to the elites of the neighbouring Congo. In February 1961, MPLA members attacked Luanda's main prison and other targets in the city. The Portuguese International and State Defence Police (PIDE), rechristened Directorate-General of Security (DGS) in 1969, immediately crushed their rebellion. Several hundred Angolans were killed in reprisals perpetrated by the police and white settlers. In March 1961, uprisings in the coffee-growing regions of northern Angola, reputedly organised by the UPA, caused the death of approximately 1,500 black Angolans and several hundred European settlers, while white reprisals and the belated reaction of the Portuguese military claimed tens of thousands of victims. As the Portuguese military presence increased dramatically over the following months, the conflict settled down into sporadic guerrilla warfare, in which the liberation movements fought both the Portuguese colonial army and each other. ${ }^{44}$

On 15 March 1961, the UN Security Council voted on a resolution put forward by Liberia that urged Portugal to introduce reforms in Angola. Although both the USSR and the US voted in favour of this resolution, it was defeated by six abstentions, including those of the UK, France, and the Republic of China. ${ }^{45}$ This breakdown of votes is indicative of the major Western powers' position during the early independence war in Angola. The Kennedy administration initially spoke out against Portugal's violent suppression of African nationalism.

43 Norrie MacQueen, The Decolonization of Portuguese Africa. Metropolitan Revolution and the Dissolution of Empire, London: Longman, 1997, pp. 1-15.

44 Ibid., pp. 18-20, 23-24. For a detailed overview of early Angolan nationalism and the outbreak of the independence war in Angola, see John A. Marcum, The Angolan Revolution. Volume I: The Anatomy of an Explosion (1950-1962), Cambridge, MA: MIT Press, 1969. Bruno Cardoso Reis, "Portugal and the UN: A Rogue State Resisting the Norm of Decolonization (1956-1974)", Portuguese Studies 29:2 (2013), pp. 251-276, pp. 262-263. 
In a radical break with his predecessor's policy, John F. Kennedy sought contact with moderate nationalist leaders in Portuguese Africa and supported several UN resolutions critical of Portuguese colonialism. From mid-1962, however, Washington's attitude changed, not least because the Kennedy administration wanted to ensure continued access to its strategically important military base on the Portuguese Azores. ${ }^{46}$ London's position was more cautious. Although the British Labour government was committed to the principle of self-determination and embarrassed about Lisbon's resistance to decolonisation, it refused to put too much pressure on its historical ally and fellow member of EFTA. The ongoing decolonisation process in British colonies was also a factor in London's discreet attitude. ${ }^{47}$ France and the FRG supported the authoritarian Estado Novo regime in Portugal, especially in the fields of military cooperation and arms sales. ${ }^{48}$

The outbreak of armed violence in Angola in 1961 quickly gained high-level attention in Switzerland. While Swiss foreign policymakers never doubted that the Portuguese territories would be decolonised in the foreseeable future, they had no inkling that the independence wars would drag on for more than fourteen years. Fearing that the situation might escalate, as it had in Algeria and the Congo, FPD leaders were concerned about the safety of Swiss citizens in Angola. More than fifty Swiss nationals left the colony between December 1960 and early July 1961. Out of the approximately 80 people that stayed, more than half were members of Protestant or Catholic missionary societies. Many of the others worked as engineers, geologists, or mechanics. In July 1961, the FPD's Secretary General, Pierre Micheli, insisted that in order to better protect Swiss citizens and interests, Switzerland's consular agency should be transformed

46 For a recent overview of different states' positions during the early independence wars, see Luís Nuno Rodrigues, "The International Dimensions of Portuguese Colonial Crisis", in Miguel Bandeira Jerónimo, António Costa Pinto (eds.), The Ends of European Colonial Empires. Cases and Comparisons, Houndsmills: Palgrave Macmillan, 2015, pp. 243-267. On the Kennedy administration's policy on Portuguese colonialism and Africa in general, see Borstelmann, The Cold War and the Color Line, pp. 135-171; Philip E. Muehlenbeck, Betting on the Africans: John F. Kennedy's Courting of African Nationalist Leaders, Oxford: Oxford University Press, 2012; Luís Nuno Rodrigues, "The United States and Portuguese Decolonization”, Portuguese Studies 29:2 (2013), pp. 164-185; Schneidman, Engaging Africa, pp. $1-58$.

47 Pedro Aires Oliveira, "Live and Let Live: Britain and Portugal's Imperial Endgame (194575)", Portuguese Studies 29:2 (2013), pp. 186-208; Glyn Stone, "Britain and the Angolan Revolt of 1961", The Journal of Imperial and Commonwealth History 27:1 (1999), pp. 109-137; Glyn Stone, "Britain and Portuguese Africa, 1961-65", The Journal of Imperial and Commonwealth History 28:3 (2000), pp. 169-192.

48 Ana Mónica Fonseca, Daniel Marcos, "Cold War Constraints: France, West Germany and Portuguese Decolonization”, Portuguese Studies 29:2 (2013), pp. 209-226. 
into a consulate before the uprisings in Angola developed into all-out war. If the situation deteriorated, the establishment of a diplomatic representation might have unwelcome political or legal consequences, notably implying Switzerland's recognition of Angola as an independent state. Micheli wished to preserve Switzerland's cordial relations with the colonial power by avoiding "too big a snub to Portugal". The consulate in Luanda was established in January 1962 and was headed by a Swiss businessman as honorary consul. ${ }^{49}$

The year 1963 started with the first attacks made by the Partido Africano da Independência da Guiné e Cabo Verde (African Party for the Independence of Guinea and Cape Verde, the PAIGC) against the Portuguese colonial authorities. The PAIGC would soon control a significant part of the territory of Guinea-Bissau and prove a greater challenge to the Portuguese military than the liberation movements in both Angola and Mozambique..$^{50}$ In May of the same year, the newly founded OAU enhanced the legitimacy of the liberation struggles in Southern Africa by providing the nationalist movements with diplomatic and material support. The OAU also decided to proceed with "the breaking off of diplomatic and consular relations between all African States and [the] Governments of Portugal and South Africa so long as they persist in their present attitude towards decolonization". ${ }^{11}$ Two months later, the Swiss government was asked to act as Portugal's protecting power in Senegal. Lisbon's choice was probably motivated by Switzerland's long experience as a protecting power. During the Second World War, Bern had simultaneously represented the interests of 35 different states in over 200 mandates. During the Cold War, it continued to be asked to undertake such mandates, most famously by the US in Cuba in $1961 .{ }^{52}$ The language factor also played a role. As French

49 Note from Pierre Micheli, Secretary General of the FPD and head of the DPA, to the AD, "Vertretung in Angola", o6.o7.1961, SFA E2004B\#1974/53\#90*; see also the attached memorandum by Edouard Brügger, DPA, "Aktennotiz betreffend Schweizerkolonie und Lage in Angola. Lage in Angola", o6.o7.1961. See also the excerpt of the minutes of the Federal Council's meeting on 10 January 1962, "Transformation de l'agence consulaire de Suisse à Luanda (Angola) en un consulat. - Nomination de M. Roland Gottraux, agent consulaire, en qualité de consul honoraire de Suisse à Luanda", pp. 1-2, ibid.

50 Norrie MacQueen, "Portugal's First Domino: 'Pluricontinentalism' and Colonial War in Guiné-Bissau, 1963-1974", Contemporary European History 8:2 (1999), pp. 209-23o, pp. 209, 212.

$5^{1}$ Resolution CIAS/Plen.2/Rev.2 adopted by the first conference of independent African heads of state and government from 22 to 25 May 1963, "Decolonization", https://au.int/ sites/default/files/decisions/32247-1963_cias_plen_2-3_cias_res_1-2_e.pdf $\quad$ (13 January 2021).

52 Thomas Fischer, "From Good Offices to an Active Policy of Peace: Switzerland's Contribution to International Conflict Resolution" in Jürg Martin Gabriel, Thomas Fischer (eds.), Swiss Foreign Policy, 1945-2002, Houndsmills: Palgrave Macmillan, 2003, pp. 74-104, p. 77. On Switzerland's representation of US interests in Cuba, see Virginie Fracheboud, "La 
is one of Switzerland's national languages, the Portuguese foreign ministry considered "that it would be very convenient if the Swiss government were to accept to take on the representation of Portuguese interests in some francophone African countries".53

The Portuguese request created a dilemma for the FPD. On the one hand, the willingness to represent the interests of third countries was part of Switzerland's active neutrality policy and helped to show the usefulness of a neutral stance. On the other hand, the department's leaders worried that acting as Portugal's protecting power might endanger Switzerland's own interests in Senegal and on the African continent. Still, the department's head concluded that there were insufficient reasons to refuse the mandate. ${ }^{54}$ Starting in mid-1963, Bern provided consular assistance to the 30,000 Portuguese nationals living in Senegal. ${ }^{55}$ Nevertheless, the FPD wanted to make it clear that representing Portugal's interests did not signify approval of its colonial policy. Accordingly, the Swiss ambassador in Senegal was ordered to mention Switzerland's readiness to defend Senegalese interests in Portugal to his host country's government. ${ }^{56}$ Such a double mandate would have minimised the risk of being perceived as the agent of a colonial power. But while Dakar gave its agreement to Switzerland representing Portuguese interests in Senegal, it showed no interest in conferring a mandate of its own. ${ }^{57}$ Egypt aside, where Franco's Spain acted as Portugal's protecting power and Brazil took on the corresponding mandate for the Nasser government, there were few Portuguese interests at stake in other African states that had severed their ties with Lisbon, and no further representation mandates were assigned. ${ }^{58}$

"In order to establish close ties of friendship with your country and government", representatives of Angolan and Mozambican nationalist movements

Suisse au service des intérêts américains à Cuba ou le succès de la politique de neutralité et solidarité (1961-1963)", Relations internationales 163:3 (2015), pp. 47-62.

Telegram no. 3 o from [?] Barreiros Martins, Portuguese Ministry of Foreign Affairs (MNE), to the Portuguese Embassy in Switzerland, 20.07.1963, Arquivo Histórico Diplomático, Lisbon, Portugal (AHD) PEA 1963, box 292.

Friedrich Traugott Wahlen, Federal Councillor and head of the FPD, proposal to the Federal Council, "Reprise éventuelle des intérêts du Portugal au Sénégal", 23.07.1963, p. 2, SFA E2OO1E\#1976/17\#4360*.

Letter from René Naville, Swiss Ambassador in Portugal, to the DPA, "Rupture de relations diplomatiques", 14.08.1963, SFA E2001E\#1976/17\#4352*.

56 Telegram no 25 from the FPD to the Swiss Embassy in Senegal, 25.07.1963, p. 1, SFA E2001E\#1976/17\#436o*.

57 Note from Raymond Probst, deputy head of the DPA, to Friedrich Traugott Wahlen, "Portugal im Verhältnis zu Drittstaaten", 26.08.1963, p. 2, SFA E2001E\#1976/17\#4352*.

58 Letter from René Naville to the DPA, "Rupture de relations diplomatiques", 14.08.1963, SFA E2001E\#1976/17\#4352*. 
contacted the Swiss embassies in Algiers and Cairo in August 1963 in their quest for international recognition. ${ }^{59}$ Raymond Probst, the deputy head of the DPA, subsequently issued guidelines on Switzerland's attitude towards liberation movements and governments in exile that would remain valid for more than a decade. In a confidential note to Swiss diplomatic and consular posts in Africa, Probst warned them to take a suitably reserved approach towards these bodies and to react with caution to possible overtures, stating: "In fact, we have to avoid anything that might be interpreted as constituting an implicit recognition of these 'governments' or movements by Switzerland". At the same time, Swiss ambassadors were at liberty to have courteous relations with representatives of liberation movements if they should meet at diplomatic events. Conscious that some flexibility was needed, Probst left the manner of such contact to the good judgment of the ambassadors. ${ }^{60}$

When the armed struggle began in Mozambique in September 1964, there was little reaction from Bern. The war was launched by the Frente de Libertação de Moçambique (Liberation Front of Mozambique, FRELIMO), which was created in 1962 at the behest of Presidents Julius Nyerere of Tanzania and Kwame Nkrumah of Ghana and united three different regional and ethnically based liberation groups. However, the Portuguese military and secret service quickly countered FRELIMO's first attacks in northern Mozambique, while internal divisions initially occupied much of its leadership's attention. These continued after the assassination of FRELImo's first President, Eduardo Mondlane, in February 1969 and ended only when former military commander Samora Machel took over the presidency in May 1970. Under his leadership, FRELIM O's Marxist orientation was consolidated. In 1972 and 1973, the liberation movement intensified its guerrilla campaign. It extended its attacks to new regions in the centre of the country, away from its strongholds in the north where it had set up schools and administrative structures in the so-called liberated areas' ${ }^{61}$

In the mid-196os, however, FRELIMO did not pose much of a threat to the Portuguese army. By this time, the FPD's interest in the liberation wars in

59 Johnny Eduardo of the Angolan Revolutionary Government in Exile (GRAE)'s Algiers office, cited in the letter from Dietrich Kappeler, chargé d'affaires ad interim (a.i.) of the Swiss Embassy in Algeria, to the DPA, confidential, 23.08.1963, SFA E2001E\#1978/84\#5724*; see also the letter from Silvio Masnata, chargé d'affaires a.i. of the Swiss Embassy in Egypt, to the DPA, confidential, 27.08.1963, ibid.

6o Notification from Raymond Probst to Switzerland's diplomatic and consular posts in Africa, the Middle East, and the Far East, "Attitude à observer à l'égard des mouvements de libération et de gouvernements en exil”, confidential, 26.o9.1963, p. 1, SFA E2001E\#1976/17\#4375.

61 MacQueen, The Decolonization of Portuguese Africa, pp. 21; 25; 43-49. 
Portuguese Africa had waned, as the conflicts stagnated and there was little sign of a change in the status quo. The issue only reappeared when the Portuguese government occasionally criticised the anti-Portuguese activities of Angolan refugees in Switzerland or of Swiss missionaries in Angola and Mozambique. However, this never seriously harmed the friendly relations between the Swiss and Portuguese governments.

In the late nineteenth century, Protestant missionaries from the Frenchspeaking part of Switzerland had established missionary stations in Portuguese Africa. The Swiss Mission was active in Mozambique and South Africa, while the Mission philafricaine set up in Caluquembe, Angola. ${ }^{62}$ The Portuguese government and secret service suspected that the missionaries did not support their colonial policies and incited the local population to insubordination. As a consequence, some missionaries were refused return visas after a holiday in Switzerland in the early 1960s. US and British Protestant missions faced similar difficulties. ${ }^{63}$ In early 1965, the F PD's Secretary General urged the Swiss ambassador in Portugal to make every effort to help the missionaries. His support of the missions despite his awareness that the Portuguese suspicions might be justified testifies to the importance that the FPD attributed to religious missions. In particular, Pierre Micheli underlined the crucial role of religious missions for the Swiss government's development aid policy. ${ }^{64}$ Until the late 196os, the Swiss federal administration did not run its own development projects in the Third World, but provided financial support to private Swiss aid agencies or multilateral organisations that had experience in this field. ${ }^{65}$ Due to their long presence in Portuguese Africa, Swiss missions were valued partners of Switzerland's policy of solidarity with the developing world. A Swiss police investigation into the activities of the Mission philafricaine concluded in early 1965 that the Portuguese accusations were unfounded. ${ }^{66}$ In the case of the Swiss Mission in

62 On the establishment of Swiss missions in Angola and Mozambique, see Didier Péclard, Ethos missionnaire et esprit du capitalisme. La Mission philafricaine en Angola 1897-1907, Lausanne: Le Fait missionnaire, 1995; Harries, Butterflies \& Barbarians; Nicolas Monnier, Stratégie missionnaire et tactiques d'appropriation indigènes. La mission romande au Mozambique 1888-1896, Lausanne: Le Fait missionnaire, 1995.

63 Political letter from René Naville to Pierre Micheli, 27.01.1965, dodis.ch/30903; letter from J. J. Galabru, French consul general in Angola, to the French foreign minister, "Difficultés missionnaires protestants en Angola", o2.09.1964, CADN, 89PO/2002021/66o.

64 Letter from Pierre Micheli to René Naville, "Voyage en Angola et au Mozambique", 27.01.1965, confidential, SFA E2001E-01\#1987/78\#4643*.

65 Catherine Schümperli, La politique suisse de solidarité internationale. De la coopération au développement global, Lausanne: Presses polytechniques et universitaires romandes, 2007, pp. 28-29.

66 Report from Inspector René Gailloz, Federal Police, to the Chief of the Police Service of the Office of the Attorney General of Switzerland, 29.01.1965, p.3, SFA E2001E-01\#1987/78\#4643*. 
Mozambique, there were clearer grounds for suspicion. The mission had close links to leading members of FRELIMO, whose first President, Eduardo Mondlane, had been a pupil of one of its mission schools. ${ }^{67}$ In 1966, the Portuguese authorities suddenly resumed granting visas to Swiss missionaries, but not to those of other nationalities. This was seen as a sign of Lisbon's satisfaction with Bern's service as a protecting power in Senegal and with the refusal of Swiss delegations to international organisations to condemn Portuguese colonialism. ${ }^{68}$

The activities of Angolan refugees in Switzerland also periodically raised red flags in Lisbon. The Swiss authorities had considerable experience in dealing with the presence of foreign nationalists. In the early twentieth century, Switzerland, with its tradition of offering asylum to political refugees, became a site of anti-colonial mobilisation for South Asian activists. ${ }^{69}$ From the mid1950s onwards, during the independence war in Algeria, a number of Algerian refugees and nationalist leaders took up residence in Switzerland. They even established organisational structures of the FLN, which led to tensions with the French government. ${ }^{70}$ The Swiss authorities' attitude towards the Angolan refugees, who numbered at least 140 people, was characterised, on the one hand, by a certain tolerance for the possible future rulers of an African state and, on the other hand, by the repression of all political activities. These were considered harmful to the credibility of Switzerland's neutrality and to its relations with the colonial power. Although some Mozambican nationalists lived in Switzerland during the independence wars, too, ${ }^{71}$ their number was smaller and they were more discreet than their Angolan counterparts. Therefore, their presence did not give rise to the same concern.

In July 1961, a first group of 19 Angolans with different political affiliations arrived in Switzerland. They had studied in Portugal and fled to France after the outbreak of armed struggle in Angola. The Hilfswerk der Evangelischen Kirchen Schweiz (relief organisation of the Protestant churches of Switzerland, HEKS) took up their cause and petitioned the Swiss government to admit them. The FPD, the Division of Police of the Federal Department of Justice and Police

\footnotetext{
67 Cruz e Silva, Protestant Churches, pp. 101-119.

68 Ribeiro, L'attitude de la Confédération suisse, p. 53.

69 Harald Fischer-Tiné, "The Other Side of Internationalism. Switzerland as a Hub of Militant Anti-Colonialism, c. 1910-1920", in Purtschert, Fischer-Tiné, Colonial Switzerland, pp. 221-258.

70 On the presence and activities of Algerian nationalists in Switzerland, see Carron, La Suisse et la guerre d'indépendence algérienne, pp. 119-130; 220-238; 265-371.

71 In 1968, for example, the Portuguese secret services noted the presence of a Mozambican nationalist student group in Switzerland: report no 1486/68 by the Mozambican section of the Portuguese secret services, 11.og.1968, confidential, Arquivo Nacional Torre o Tombo (ANTT), Lisbon, Portugal, PIDE/DGS, Cl (2), no 4312, NT 7342.
} 
(FDJP), and the Immigration Police agreed, on condition that the refugees abstain from all political activities during their stay in Switzerland. ${ }^{72}$ In the following year, the anti-Communist Verein Schweizer Freunde Angolas (Association of Swiss Friends of Angola, vSFA) convinced the Swiss authorities to grant entry permits to several smaller groups of Angolan students. Founded in April 1961, the association supported the independence of Angola and aimed to counter Communist influence in Switzerland by awarding scholarships for a Western education to selected UPA members. The VSFA's president, Walter Artho, was a student leader at the University of Fribourg and was in close contact with Holden Roberto and with Jonas Savimbi, the secretary of the UPA and later one of Angola's principal nationalist leaders. Savimbi had arrived in Switzerland in 1959 or 1960 and studied in Fribourg and Lausanne. ${ }^{73}$

In early 1961, the Portuguese ambassador in Bern protested against the 'antiPortuguese' activities of "representatives of Angolan terrorist movements" in Switzerland. Federal Councillor and Foreign Minister Max Petitpierre replied that, while "we often grant hospitality to foreigners coming to us", the Office of the Attorney General of Switzerland was conducting an inquiry into the activities of Jonas Savimbi and the vsfa. ${ }^{74}$ As a consequence, Savimbi was interrogated by the police and cautioned to refrain from all political activities in Switzerland. ${ }^{75}$ This was not fully enforced. The Angolan refugees were systematically placed under surveillance. Due to his political role in the liberation struggle, Swiss police services monitored Savimbi particularly closely, but they were more lenient with him than with MPLA members. Up until his final departure from Switzerland after the completion of his studies in July 1965, they always agreed to extend his residence permit. In 1966, Savimbi launched his own liberation movement, the União Nacional para a Independência Total de Angola (National Union for the Total Liberation of Angola, UnITA) based in eastern Angola. Its formation completed the tripartite structure of Angolan nationalism. During the independence war, the MPLA, the FNLA, and UNITA attacked each other as well as the Portuguese and competed for foreign recognition and assistance. This probably contributed to the fact that the three liberation move-

72 Kurmann, 'Affaires angolaises', pp. 30-36, 46-47.

73 Ibid., pp. 37-43. Savimbi made contradictory statements about the time of his arrival in Switzerland. It was not until 1961 that his presence came to the attention of the Office of the Attorney General of Switzerland: Ibid., pp. 85-87.

Max Petitpierre, Federal Councillor and head of the FPD, "Entretien avec M. Guerra, Ambassadeur du Portugal, le mardi 23 mai 1961, à 15 h. 45”, no date, citations p. 1, 2, dodis. ch/15227. See also Edouard Brugger, DPA, memorandum, "Notiz über die Besprechung mit Herrn Walter Artho. Angola", confidential, 16.05.1961, dodis.ch/15225. 
ments never seriously threatened the colonial power. After the fall of the Portuguese colonial empire in 1974, their rivalry would escalate into the Angolan War of $1975^{-1976}$ that ended with the victory of the Soviet-allied MPLA. ${ }^{76}$

In the early 196os, the Angolan students were not granted official refugee status in Switzerland. As a consequence, their residence permits had to be renewed regularly and they were not entitled to state scholarships. Yet, they could count on an important support network. The financial aid and mentoring of the Angolan students was ensured to a large degree by national and international organisations such as the VSFA, the Catholic relief organisation Caritas, HEKs, the World Council of Churches (WCC), and the World University Service, as well as private companies and individuals. ${ }^{77}$ Thus, the Swiss government was able to show its support for Angola's potential future elites at minimal financial cost, while their uncertain legal status would have made it easy to expel them if Portuguese objections had become too vocal.

This changed in early 1968, when a number of Angolan refugees received political asylum in Switzerland. Hans Mumenthaler, head of the Division of Police's Welfare Section, was sympathetic to this request, as the Angolan refugees were persecuted by the Portuguese government and had de facto benefited from political asylum in Switzerland for years. He suggested, however, that the refugees should be encouraged to leave Switzerland as soon as conditions in Angola permitted or once they had the opportunity to live in a friendly African state. Partly, this was an expression of Bern's conviction that the admission and training of the refugees was a contribution to Angola's future development and that the students had important duties to fulfil in Africa. At the same time, this suggestion was also grounded in racism: "members of coloured races", Mumenthaler argued, would find it difficult to live permanently in a European country. ${ }^{78}$ In January 1968, 28 Angolans and their families made a collective application for political asylum in Switzerland; as long as "no overly bad elements are included", the Welfare Section was willing to look upon the cases with benevolence. ${ }^{79}$ Inspector René Gailloz of the Federal Police, who regularly checked up on the refugees, also recommended accepting the collective

$7^{6} \quad$ Kurmann, 'Affaires angolaises', pp. 85-100. The most detailed analysis of the three Angolan liberation movements' rivalry between 1962 and 1976 is Marcum, Exile Politics and Guerrilla Warfare.

$77 \quad$ Kurmann, 'Affaires angolaises', pp. 32-33, 41, 52 .

78 Note from Hans Mumenthaler, head of the Division of Police's Welfare Section in the FDJP, to Ludwig von Moos, Federal Councillor and head of the FDJP, "Angolesische Flüchtlinge", o8.o1.1968, p. 2, SFA E428oA\#1998/296\#489*; see also Mumenthaler, memorandum, 19.12.1967, ibid.

79 Note from Hans Mumenthaler to Philippe Chappatte, FDJP, 24.01.1968, SFA E428oA\#1998/ $296 \# 489$ *. 
application, because "the political agitation in these milieus has fairly calmed down". ${ }^{80}$ Although several of the applicants had, in the past, been cautioned for being politically active, it was only in the cases of two members of the "little MPLA clan in Lausanne" that Gailloz spoke out against their recognition as political refugees. ${ }^{81}$ In April 1968, the Division of Police accepted 20 out of the 28 applications and a total of 32 Angolans were granted status as political refugees, including the two MPLA members that had raised Gailloz's suspicion. ${ }^{82} \mathrm{~A}$ further 20 applications were accepted up until $1975 .{ }^{83}$

As the independence wars in Angola and Mozambique dragged on, most other African colonies gained independence, and Portuguese colonialism was subsumed in the increasingly heated international debate on white minority rule in Southern Africa, the priorities of Swiss foreign policymakers changed. During the late independence wars between 1967 and 1974, they would focus less on preparing for decolonisation than on avoiding any action that might impair their political, economic, and financial relations with Portugal and, by extension, with South Africa and Rhodesia.

Swiss Business in Sub-Saharan Africa

Specialists in Swiss foreign relations have frequently underlined the crucial role of economic and financial interest in the shaping of Swiss foreign policy. They showed how commercial interests determined foreign policy decisions and underlined the strong influence of business leaders and industrial associations in Bern. ${ }^{84}$ Although the African continent made up less than $5 \%$ of Switzerland's

8o Cited in Philippe Chappatte, memorandum, 04.o3.1968, SFA E4280A\#1998/296\#489*.

81 Report by Inspector René Gailloz, Federal Police, to the head of the Police Service of the FDJP, "ANGOLAIS et autres Africains originaire des territoires portugais d'outre-mer. Demande d'asile politique en Suisse”, 29.03.1968, p. 3, SFA E4280A\#1998/296\#489*, see also pp. 7-8.

82 No author, table, "Personen, die von der Eidg. Polizeiabteilung mit Entscheid vom 11.4.1968 als Flüchtlinge anerkannt worden sind", no date, SFA E428०A\#1998/296\#489*; no author, table, "Personnes reconnues comme réfugiés par décision de la Division fédérale de police du 11 avril 1968", no date, ibid.

83 Kurmann, 'Affaires angolaises', p. 6o.

84 Dominique Dirlewanger, Sébastien Guex, Gian-Franco Pordenone, La politique commerciale de la Suisse de la Seconde Guerre mondiale à l'entrée du GATT (1945-1966), Zurich: Chronos, 2004, pp. 15-16. Notably, see also Cedric Humair, "Commerce extérieur et politique commerciale aux 19e et 2oe siècles”, Traverse 17:1 (2010), pp. 184-202; the articles in Hans Ulrich Jost, Monique Ceni, Matthieu Leimgruber (eds.), Relations internationales et affaires étrangères suisses après 1945, Lausanne: Éditions Antipodes, 2006; Marc Perrenoud, "Politique économique et relations extérieures", Traverse 17:1 (2010), pp. 171183; Janick Marina Schaufelbuehl, La France et la Suisse ou la force du petit. Évasion fiscale, relations commerciales et financières (1940-1954), Paris: Presses de Sciences Po, 2009. 
total foreign trade in the twentieth century, economic motives played an important role in determining its government's foreign policy during decolonisation. Swiss foreign policymakers sought to establish cordial relations with independent African governments in order to gain access to essential raw materials and expand into new markets. The departure of the colonial powers would, they hoped, open the way for Switzerland's export industry. The conclusion of bilateral investment protection agreements, intended to facilitate Swiss investments in developing countries, was an established part of Swiss policy in sub-Saharan Africa. ${ }^{85}$ Analysis of Switzerland's economic role in Southern Africa and the Horn therefore allows an evaluation of the importance of economic considerations on Swiss decision-making during the regime changes and armed conflicts in Angola, Mozambique, Ethiopia, and Somalia. This is even more important as Switzerland's economic and financial role in the global South was the main source of contention between Bern and Afro-Asian leaders in the late 196os and 1970s. As Swiss commercial exchanges with and investments in the Horn of Africa were very limited, this analysis focuses mostly on the Portuguese colonies, where relations with the colonial power were paramount.

Considering the dearth of official Swiss statistics, it is extremely difficult to get a reliable picture of the four African states' importance for Swiss economic circles. The trade statistics established by the Swiss customs authorities only include goods that physically crossed the Swiss border. These constitute only a small part of the total purchases and sales effected by Swiss firms and thus provide a partial picture of bilateral commercial exchanges. Information about Swiss foreign direct investment is even more vague due to a complete lack of statistical data for the period under consideration. The strong resistance of influential Swiss economic and financial elites ensured that it was not until the mid-1980s that the Swiss authorities started to publish statistics on Switzerland's balance of payments. Even then, information on foreign direct investment remained incomplete. ${ }^{86}$ In addition, it is difficult to disentangle Switzerland's economic relations with Angola and Mozambique from those with the Portuguese colonial power, as well as with neighbouring South Africa and Rhodesia. A rare diplomatic correspondence permits the assessment of the limits of bilateral trade statistics and the distorting effect of indirect trade; the Swiss ambassador in Ethiopia reported that in 1979, the food group Nestlé imported goods worth CHF 21 million from Angola and sold goods worth CHF 19 million there, while the trading firm André \& Cie had a turnover of CHF 309.7 million in the

85 Perrenoud, "Les relations de la Suisse avec l'Afrique".

86 Sébastien Guex, Janick Marina Schaufelbuehl, "Les vertus de l'ignorance. Enjeux et conflits autour des statistiques sociales et économiques en Suisse au XXe siècle", Économies et Sociétés 44:9 (2011), pp. 1555-1574, p. 1565. 
country. Thus, commercial exchanges with Angola by far exceeded the CHF 7.9 million (imports) and CHF 19 million (exports) indicated in the official Swiss trade statistics for that year. ${ }^{87}$ However, Swiss foreign policymakers rarely had detailed information about Swiss firms' activities in Africa at their disposal and based their policy decisions on the available approximate data.

Looking at Swiss trade with sub-Saharan Africa between 1961 and 1979, it seems clear that none of the four African states selected for this study was a major commercial partner for Switzerland. Table 1 shows that their combined weight in Switzerland's total trade with sub-Saharan Africa never reached $10 \%$, excepting the years immediately before the independence of Angola and Mozambique - when imports from Portuguese Africa made up $10.3 \%$. Of the four states, Angola had the biggest share of Switzerland's total trade with sub-Saharan Africa, while trade with Somalia was negligible. The shares of Angola, Mozambique, and Ethiopia in Switzerland's total imports from and exports to sub-Saharan Africa dropped after the regime changes in the mid-1970s. ${ }^{88}$ The limited information available suggests that Switzerland was not an important commercial partner for the African states, either. ${ }^{89}$ Table $1^{90}$

87 Letter from Fritz Bohnert, Swiss ambassador in Ethiopia, to the Trade Division, "Angola: Informationen über die Wirtschaft”, 21.10.1980, SFA E2001E-01\#1991/17_Bd.611, C.41. Angola.10o.o; Historical Statistics of Switzerland Online (HSSO) database, developed under the supervision of the Swiss Society for Economic and Social History in collaboration with the Universities of Zurich, Geneva and the Federal Institute of Technology Lausanne, https://hsso.ch/en (11 August 2021), tables L.20, "Einfuhrwerte nach Ursprungsländern 1920-1992 (in Millionen Franken): Afrika”, L.24, "Ausfuhrwerte nach Verbrauchsländern 1920-1992 (in Millionen Franken): Afrika". The sum of US $\$ 120$ million has been converted to $\mathrm{CHF}$ using the exchange rates indicated in Lawrence H. Officer, "Exchange Rates Between the United States Dollar and Forty-one Currencies", Measuring Worth, 2018, https://www .measuringworth.com/datasets/exchangeglobal/ (13 January 2021).

88 HSsO database, tables L.20, "Einfuhrwerte nach Ursprungsländern 1920-1992 (in Millionen Franken): Afrika”, L.24, "Ausfuhrwerte nach Verbrauchsländern 1920-1992 (in Millionen Franken): Afrika".

89 From the 12 member states of the EEC and EFTA, Switzerland was, in 1968, the sixth most important buyer country of Angola, while it occupied the ninth place as a supplier: letter from René Naville to Pierre Micheli, 16.o8.1968, p. 14, SFA E2001E\#198o/83\#3788*. In 1973, imports from Switzerland constituted $2.4 \%$ of Mozambique's total imports, and the share of exports was with $0.1 \%$ even lower: Louis Chaney, Swiss consul in Mozambique, memorandum, "Mozambique", o1.11.1974, SFA E2004B\#199o/219\#373*. In 1966, Switzerland was the 17th most important provider of goods for Ethiopia and the 19th most important buyer: II, chargé d'affaires a.i. Swiss Embassy in Ethiopia, to the Trade Division, "Rapport économique", o3.08.1967, pp. 2-6, SFA 7110\#1978/50\#1358*.

90 Hsso Database, tables L.20, "Einfuhrwerte nach Ursprungsländern 1920-1992 (in Millionen Franken): Afrika", L.24, "Ausfuhrwerte nach Verbrauchsländern 1920-1992 (in Millionen Franken): Afrika" 


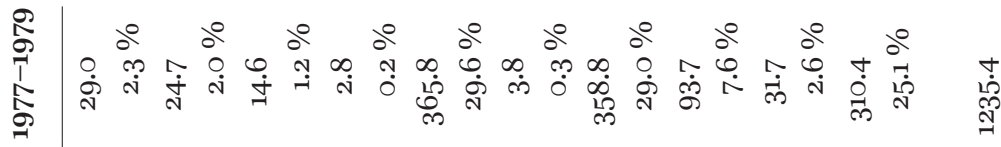

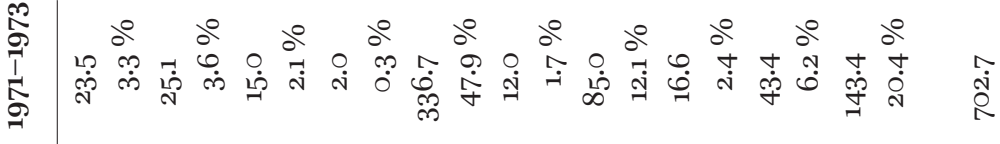

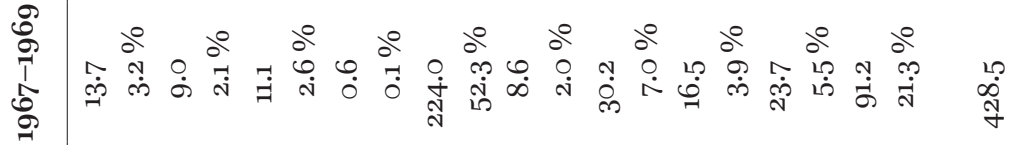

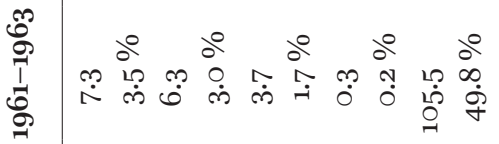

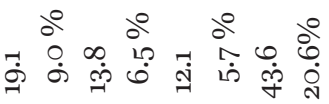

$\stackrel{\infty}{\text { กี }}$

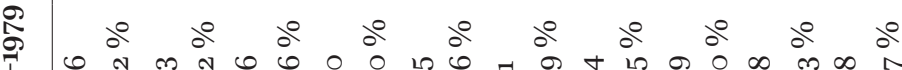
点

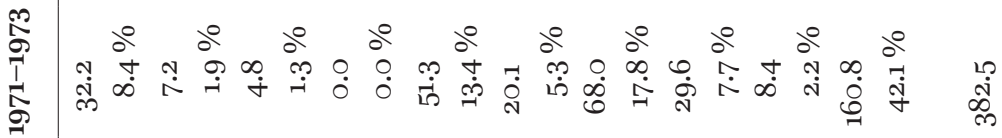


highlights the preponderance of South Africa in Switzerland's trade with subSaharan Africa, particularly with regard to exports. Between 1961 and 1973, South Africa absorbed about $50 \%$ of all Swiss exports to this part of the world. In the late 1970s, South Africa's share still amounted to almost 30\%, closely followed by Nigeria. In the late 196os and early 1970s, Swiss imports from Rhodesia amounted to $5 \%$ of Switzerland's total imports from sub-Saharan Africa, while Swiss exports to the Smith regime were not significant.

The importance of Switzerland's economic links with South Africa and Rhodesia was much greater than these countries' shares in its total trade with sub-Saharan Africa suggests. Bilateral relations with the Apartheid regime were particularly intense in the fields of capital exports to South Africa and imports of South African gold. Between 1968 and 1974, Swiss direct and indirect investment in South Africa constituted on average $7.6 \%$ of all foreign investment in the country and reached almost CHF 4,00o million in 1974. During the same period, more than $80 \%$ of South Africa's gold was commercialised through banks in Zurich. ${ }^{91}$ With the Swiss-South African Association (sSAA), which was founded in 1956 to promote and protect Swiss economic interests in South Africa and which included leading members of the major Swiss export firms and banks, the Apartheid regime had a strong lobby in Switzerland. ${ }^{92}$ Alongside its close economic, financial, and political relations with Pretoria, Switzerland's non-participation in the UN sanctions against Rhodesia also laid its government open to attacks from Third World leaders and Swiss civil society actors. After Rhodesian Prime Minister Ian Smith's white minority regime made a unilateral declaration of independence from the UK in November 1965 , Bern decided not to participate in UN economic sanctions against Rhodesia. Instead, future Swiss imports from Rhodesia were restricted to the levels of 1964-1965, the so-called courant normal. These allegedly autonomous measures were a result of direct British pressure and the Swiss government's

$91 \quad$ Bott, La Suisse et l'Afrique du Sud, pp. 276; 279; 373, and p. 386 for the exchange rates between rand and CHF. For an overview of Switzerland's relations with South Africa during the second half of the $20^{\text {th }}$ century, see also Kreis, Die Schweiz und Südafrika.

92 On this association, see David Gygax, La Suisse-South African Association (1956-200o). Un organe du capital helvétique en Afrique du Sud, Fribourg: Chaire d'histoire contemporaire de l'Université de Fribourg, 2001. A similar, but more low-key and less influential organisation existed to promote Swiss economic interests in Rhodesia: Rahel Stauffiger, 'Behind the Scenes'. Die Gesellschaft Schweiz-Rhodesien zwischen diskreter Beziehungspflege und offizieller Schweizer Rhodesienpolitik, unpublished Master thesis, University of Fribourg, 2018; Mathias Ulrich, 'Die Sache Rhodesiens in der Schweiz vertreten'. Funktion und Netzwerk der Gesellschaft Schweiz-Rhodesien, 1965-1980, unpublished Master thesis, University of Zurich, 2019. 
fear of negative Afro-Asian reactions if Switzerland were to be seen to benefit economically from other states' sanctions. ${ }^{93}$

Figure $1^{94}$ gives an overview of the development of Switzerland's commercial exchanges with Angola, Mozambique, Ethiopia, and Somalia between 196o and $1985 .{ }^{95}$ With the exception of Angola, Switzerland's trade balance with the four African countries was largely positive throughout this period. For a country forced to import a large part of the raw materials needed for its industry, this was important, as it helped to reduce its chronic foreign trade deficit.

The Angolan and Mozambican markets of the late 196os and early 1970s were very dynamic. Swiss imports from Angola grew steadily during the 196os and reached their highest level in 1973 with goods worth CHF 45.6 million being imported in that year. Swiss exports to both countries also increased steadily in the 196os. Between 1966 and 1973, exports to Mozambique quadrupled in real value, and almost tripled in the case of Angola. It could be argued that the independence wars had a positive effect on Switzerland's trade with the Portuguese colonies, as bilateral trade probably benefited from the colonial authorities' increased efforts to promote the industrialisation and economic development of Portuguese Africa. These efforts were part of a series of economic and social reforms destined to counter international criticism of Portugal's colonial rule and to win the 'hearts and minds' of the Angolan and Mozambican populations after the outbreak of armed struggle. ${ }^{96}$ After the Portuguese Revolution

93 FPD, FDEA, proposal to the Federal Council, "Rhodesien", urgent, 13.12.1965, attached to the Decree of the Federal Council, "Rhodesien", 17.12.1965, dodis.ch/31953. On Switzerland's policy of neutrality and its position towards the UN sanctions against Rhodesia, see Gabriel, "Switzerland and Economic Sanctions"; Letsch, Rhodesien, die Vereinten Nationen und die Schweiz”; Ross, Neutrality and International Sanctions, especially pp. 157-185.

94 Hsso Database, tables L.20, "Einfuhrwerte nach Ursprungsländern 1920-1992 (in Millionen Franken): Afrika", L.24, "Ausfuhrwerte nach Verbrauchsländern 1920-1992 (in Millionen Franken): Afrika". Data was adjusted to inflation $(1973=1)$ using the Swiss wholesale price index: table H.ga, "Grosshandelsindex nach Monaten Januar 1926 bis 1993 Mai (Juli 1914 = 100)".

95 Until 1975, the Swiss Foreign Trade Statistics only contain information about Switzerland's commercial exchanges with Portuguese West Africa, which includes Angola and GuineaBissau. However, the figures for the five following years show that Switzerland's imports from Angola were on average 13 times higher than those from Guinea-Bissau. With a ratio of 34:1, exports to Guinea-Bissau were even more negligible. Therefore, and for reason of comparability, I continue to use figures for Portuguese West Africa for the years of 1976 and later.

96 On economic and social reforms in the Portuguese colonies during the independence wars, see Gervase Clarence-Smith, The Third Portuguese Empire, 1825-1975. A Study in Economic Imperialism, Manchester: Manchester University Press, 1985, pp. 194-195, 214-217; Yonah N. Seleti, "The Development of Dependent Capitalism in Portuguese Africa", in Zbigniew A. Konczacki, Jane L. Parpart, Timothy Shaw (eds.), Studies in the Economic 


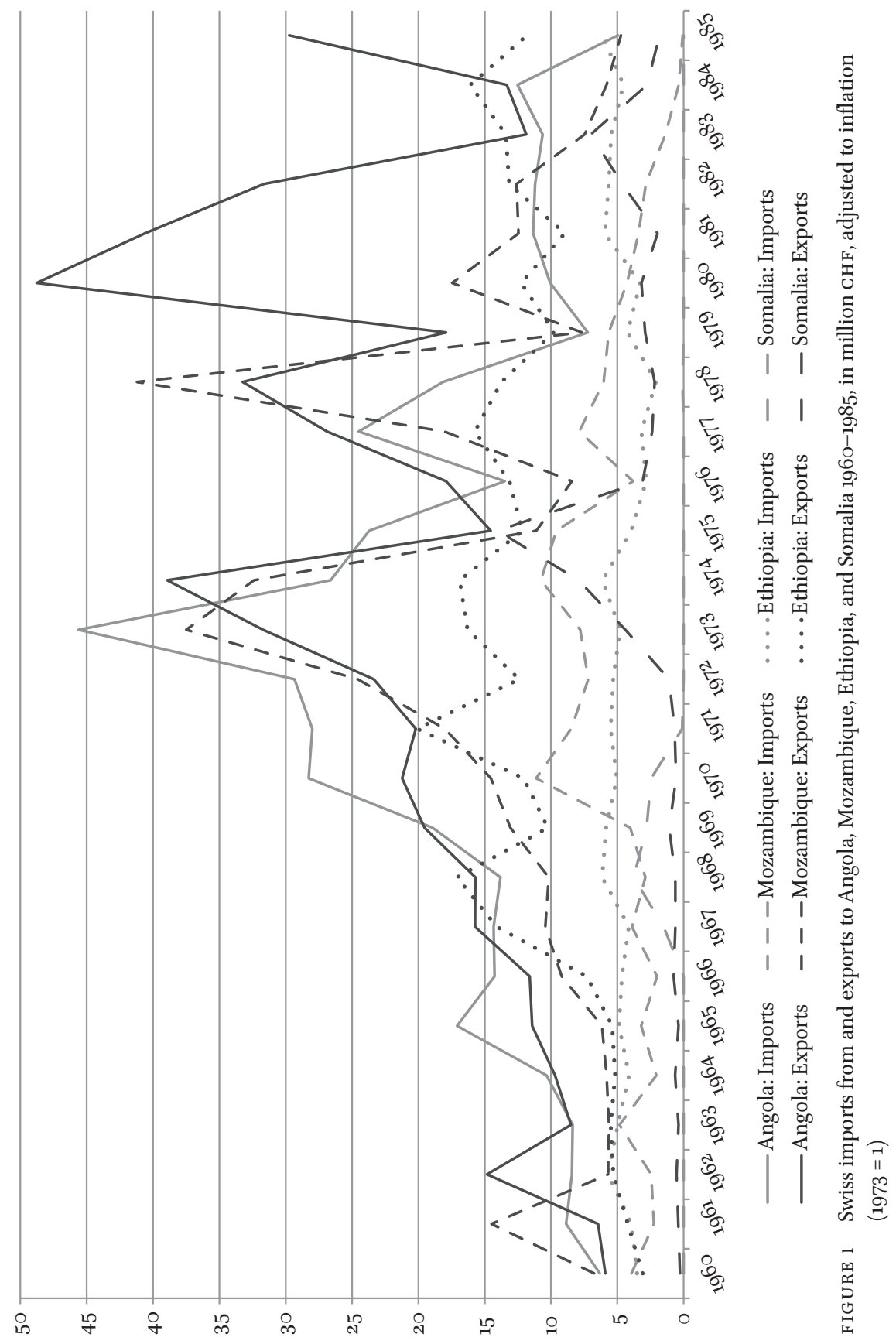


in 1974, Swiss imports and exports fell immediately. Uncertainty about the future of the colonies, which became independent in 1975, temporarily slowed trade. In 1977, exports to both countries grew again and reached their highest level a few years later, with goods worth CHF 45 million (in real value) exported to Mozambique in 1978 and CHF 58.1 million (in real value) to Angola in 1981. After this peak, Swiss exports to Mozambique fell sharply and by the mid1980 s, they had stagnated at a low level. By this time, Switzerland's imports from Mozambique had dwindled to less than CHF 0.4 million per year. This was due to armed conflicts, natural disasters, and radical economic reforms that crippled the young state's development and destabilised its economy. ${ }^{97}$

The low level of bilateral trade between Switzerland and Somalia and the correspondingly large influence of single deliveries in the trade statistics make it difficult to draw significant conclusions about the influence of the 1969 coup d'état on commercial relations. The rise in Swiss exports to Somalia in the early 1970s, which reached their highest level in 1975 with the export of goods worth CHF 15.9 million, is explained by particularly high levels of deliveries of machines as engineering company Sulzer equipped a textile firm in Somalia. The Swiss machine industry perhaps profited in a very small way from the limited economic growth that Somalia experienced in the first half of the $1970 s .{ }^{98}$ With regard to Ethiopia, it must first be noted that in the period under consideration, this state was one of Africa's least developed countries and was poorly industrialised. The productivity of the large agricultural sector was hindered by a lack of technology and infrastructure and, more importantly, the traditional system of land tenure and feudal mode of production. Despite widespread poverty, the aristocracy and the Orthodox Church had repeatedly resisted attempts at land reform. As a consequence, Ethiopia was heavily dependent on external loans and assistance. ${ }^{99}$ Nevertheless, Swiss exports to this state grew strongly in the late 196os. The political, social, and economic upheavals following the 1974 Ethiopian Revolution then led to a slight drop in

History of Southern Africa. Volume I: The Front-Line States, London: Frank Cass, 199o, pp. 30-74, pp. 63-70.

97 Malyn Newitt, "Mozambique", in Patrick Chabal, A History of Postcolonial Lusophone Africa, Bloomington: Indiana University Press, 2002, pp. 185-235, pp. 195-212.

98 Swiss Directorate General of Customs, Jahresstatistik des Aussenhandels der Schweiz, 1967-1979; see also RH, memorandum, "Téléphone le 27 février 1979 de M. Piottet de l'OSEC/Lausanne", o2.03.1979, SFA E2O25A\#1991/168\#1648*, Laitin, Samatar, Somalia, pp. $116-119$.

99 Shiferaw Jammo, "An Overview of the Economy 1941-74", in Shiferaw Bekele, An Economic History of Ethiopia, Vol. I: The Imperial Era 1941-74, Dakar: CODESRIA, 1995, pp. 1-71, mainly pp. 49, 54 . 
both imports and exports. Yet, by the early 1980s, Swiss imports from Ethiopia had again reached the levels of the 196os and early 1970s. This may be linked to the conclusion of a supply contract between the Ethiopian Minister for Coffee and André \& Cie in early 1979, which granted the Lausanne-based trading firm a right of first refusal for all coffee offered to a number of Western European states. ${ }^{100}$

Switzerland's main import commodities from the four African countries were raw materials, predominantly coffee, and its exports were primarily chemical products, followed by machines. Between 1967 and 1979, coffee accounted for $70-90 \%$ of all goods imported from Angola. In the period 1970-1974, Angola was Switzerland's fourth most important supplier of coffee, with annual average coffee imports worth CHF 24 million, which constituted 8.8\% of Switzerland's total coffee imports. Before the Ethiopian Revolution, almost $6 \circ \%$ of Switzerland's imports from this country consisted of coffee, Ethiopia's main export commodity. In 1977-1979, that figure rose to 93\%. Before Mozambique's independence, Swiss imports from this country were more varied, although cotton made up 50\% of imported goods in the early 1970s. By the end of the decade, coffee, which Switzerland had not imported from Mozambique prior to independence, made up more than $8 \circ \%$ of total imports from Mozambique or an average of CHF 6 million per year. ${ }^{101}$ Chemicals comprised almost $6 \circ \%$ of Swiss exports to both Mozambique and Angola in 1977-1979. In the boom years of 1972-1974, machines enjoyed a share of $50 \%$ in the former and $30 \%$ in the latter country. In the 1970s, chemicals made up more than $50 \%$ of Swiss exports to Ethiopia. In 1979, the Swiss multinational group Ciba-Geigy was responsible for a third of Ethiopia's imports of agrochemicals, which made it the biggest supplier. The share of watches grew during the observed period, reaching $20 \%$ of Swiss exports to Ethiopia in the late 1970s. In 1966, Swiss watches had a market share of $90 \%$ in Ethiopia. ${ }^{102}$

100 Letter from Fritz Bohnert, Swiss ambassador in Ethiopia, to the Trade Division, "Aethiopiens Export: nach dem Westen orientiert. André Lausanne”, 03.07.1979, p. 2, SFA E7115A\#1990/6o\#1351*.

101 HSSO database, table L.42a, "Einfuhrwerte einzelner Produkte nach den wichtigsten Ursprungsländern (in Millionen Franken): Mittel der Jahre 1970-1973”; Swiss Directorate General of Customs (ed.), Jahresstatistik des Aussenhandels der Schweiz, Bern, 1967-1979; Shiferaw Jammo, "An Overview of the Economy", p. 42.

Swiss Directorate General of Customs, Jahresstatistik des Aussenhandels der Schweiz, 1967-1979; II, charge d'affaires a.i. Swiss Embassy in Ethiopia, to the Trade Division, "Rapport économique", o3.08.1967, pp. 2-6, SFA 7110\#1978/50\#1358*; letter from Fritz Bohnert to the Trade Division and the STC, "Industrielle Vorhaben in Aethiopien", 19.11.1979, SFA E7115A\#1990/60\#1351*. 
The lack of statistical data makes it impossible to gain a clear picture of Swiss direct investment in Angola, Mozambique, Ethiopia, and Somalia. It was certainly not considerable in the Horn of Africa. Switzerland's financial and economic elites showed little interest in Ethiopia and almost none in Somalia. Jean Demaurex, a relative of Jean André whose family controlled one of the biggest Swiss trading firms, André \& Cie in Lausanne, founded several plantations in Ethiopia. Demaurex wholly owned the firm Cafex Private Ltd Co., established in 1956 in order to promote the sale of Ethiopian coffee in Europe. He later developed Tana Plantation Co., one of the biggest coffee plantations in Ethiopia, and in 1967, with the aid of several investors, Bilate Agricultural Estate. By 1975, André \& Cie held a majority participation of CHF 24 million in the latter two plantations. ${ }^{103}$ In 1969 , several Swiss firms were awarded contracts for the delivery of machines for the construction of hydroelectric power plants at the Awash and Fincha dams. ${ }^{104}$ Swiss insurance interests in Ethiopia thrived in the early 1970s. The reinsurance company Swiss Re alone had a yearly turnover in Ethiopia of about CHF 2 million. ${ }^{105}$ Even if few of the big Swiss banks, insurance companies, and major firms seemed interested in investing in Ethiopia, those investors present were eager to secure their assets through an investment protection agreement. In July 1970, the Trade Division therefore instructed the Swiss ambassador in Ethiopia to discuss this possibility with the Ethiopian authorities. Although the Ethiopian Foreign Minister verbally confirmed his country's interest in concluding such an agreement, periodical reminders from the Swiss embassy in Addis Ababa never received an official reply. It was not until 1998 that the two states would finally conclude a bilateral agreement to promote and protect investments. Negotiations initiated in 1971 on an aviation agreement also stalled and were disrupted by the Ethiopian Revolution. ${ }^{106}$

103 Letter from businessman Jean Demaurex to General Teferi Bante, chairman of the PMAC, 12.08.1975, attached to the letter from Jean Demaurex to Olivier Exchaquet, Swiss ambassador in Ethiopia, 12.08.1975, SFA E2001E-o1\#1987/78\#2798*; Claude Hugenin, DPA, memorandum "Garantie contre les risques de l'investissement: cas André / Ethiopie", 03.07.1975, SFA E2001E-o1\#1987/78\#2787*.

104 Letter from Fernand Bernoulli to the AD, "Schlussbericht des Missionschefs von Addis Abeba", confidential, 07.07.1970, p. 4, dodis.ch/37162; letter from Heinz Langenbacher to the STC, "Ethiopian Electric Light and Power Authority' (E ELPA): Finanzgesuch", 19.07.73, p. 1, SFA E2001E-o1\#1991/17_Bd.759, C.41.152.Eth.o.

105 Letter from Heinz Langenbacher to the STC, "Stipendium", 16.03.1972, SFA E2001E-o1\#1988/ $16 \# 3195^{*}$.

106 Letter from Fernand Bernoulli to the Trade Division, 28.05.1970, confidential, SFA E7110\#1981/41\#1188*; letter from Hans Bühler, Vice-Director of the Trade Division, to the Swiss embassy in Addis Ababa, "Investitionsschutzabkommen Äthiopien", o8.07.1970, ibid.; note 
Switzerland's economic role during the independence wars in Angola and Mozambique and its investments in the two colonies cannot be understood without looking briefly at its links with the colonising power. Switzerland's trade with and investments in Portugal increased after the two states became founding members of EFTA in 196o. At this time, Portugal had one of the least developed economies in Western Europe. Following its accession to EFTA, the Estado Novo regime relaxed its protectionist policy and Portugal's trade moved increasingly away from the colonies and towards the member states of EFTA and the EEC. At the same time, thanks to the independence wars, Portugal's military spending claimed about half of its budget. ${ }^{107}$ Bilateral commercial exchanges increased steadily between 1960 and 1974, with Swiss exports to Portugal always exceeding imports by a ratio of between 2:1 and 3:1. Between 1967 and 1974, exports to Portugal varied between 1.06\% and 1.38\% of Switzerland's total exports, imports never even reached $0.5 \%$. Although Portugal's market share of Switzerland's total foreign trade was small, it was still many times greater than that of its colonies. Swiss exports to Angola and to Mozambique only exceeded $0.1 \%$ of total Swiss exports in the years immediately before independence. The share of imports was even lower. ${ }^{108}$ Even bearing in mind that until 1974 at least part of Switzerland's imports from Portugal comprised colonial products, it is clear that the colonial power was a more important trading partner than either of its colonies.

In the early 1960s, the Portuguese government actively sought to strengthen its economic relations with Switzerland. But while Swiss industrial and banking circles were, in principle, favourably disposed towards increased economic and financial collaboration with Portugal, the latter's economic backwardness

from Sa to Hans Bühler, "Investitionsschutzabkommen Aethiopien, 22.05.1970, ibid.; letter from Fernand Bernoulli to the Trade Division, "Aethiopien: Investitionsschutzabkommen", 30.07.1970, ibid.; letter from Heinz Langenbacher to Bernhard Müller, "Investitionsschutzabkommen mit Aethiopien”, urgent, o1.11.1971, SFA E610oB-o2\#1986/168\#1720*; Langenbacher, report "Schlussbericht: Pendente Fragen und Hinweise", 14.04.1975, pp. 3-4, dodis.ch/39827; "Abkommen zwischen der Schweizerischen Eidgenossenschaft und der Demokratischen Bundesrepublik Äthiopien über die Förderung und den gegenseitigen Schutz von Investitionen", concluded on 26 June 1998 and in force since o7 December 1998, https://www .admin.ch/opc/de/classified-compilation/200106o6/index.html (13 January 2021). MacQueen, The Decolonization of Portuguese Africa, pp. 49-51.

108 Hsso database, tables L.3, "Bilanz des Aussenhandels und Zollerträgnisse nach Warenarten 1886-1992 (1)", L.18, "Einfuhrwerte nach Ursprungsländern 1920-1992 (in Millionen Franken): Europa", L.20, "Einfuhrwerte nach Ursprungsländern 1920-1992 (in Millionen Franken): Afrika", L.22, "Ausfuhrwerte nach Verbrauchsländern 1920-1992 (in Millionen Franken): Europa", L.24, "Ausfuhrwerte nach Verbrauchsländern 1920-1992 (in Millionen Franken): Afrika". 
and colonial wars were considered an obstacle to investment, whereas its lack of democratic government was apparently not. ${ }^{109}$ For its small size, Swiss direct investment in Portugal was considerable. While the UK was by far the largest foreign investor in the Southern European state in 1968, Switzerland was ranked seventh among US and Western European investors in the Portuguese industrial and commercial sectors. ${ }^{110}$ Portugal initiated negotiations, starting in 1968, which led to the establishment of a convention for the avoidance of double taxation in June 1973. The FDF insisted that Portugal was the principal beneficiary of this treaty, as it needed to attract Swiss investment to "help bring the country out of its industrial under-development".111 In November 1973, the Portuguese government sent a delegation to Bern to discuss the possibilities for increasing economic collaboration between Switzerland and Portugal. With the agreement of interested Swiss companies and trade associations in the chemicals and machines sectors, the two delegations agreed to pursue efforts to strengthen bilateral industrial cooperation. ${ }^{12}$ These efforts were interrupted by the April 1974 Carnation Revolution in Portugal and would only be resumed in late 1976 .

Moving from Europe to Africa, foreign investment in Angola and Mozambique increased rapidly after Portugal liberalised its economic policy in the early 196os. Historians Miguel Bandeira Jerónimo and António Costa Pinto underline the crucial role of foreign investment for the colonial economy during the independence wars and stress the need for further research on this subject. ${ }^{113} \mathrm{In}$

109 Paul Rudolf Jolles, Trade Division, memorandum, "Notiz über die Sitzung der schweizerischen Delegation vom 30. Oktober 1963 in Bern betreffend die wirtschaftliche Zusammenarbeit mit Portugal", no date, p. 2, dodis.ch/30691.

11 Letter from René Naville to the Trade Division, 29.07.1969, SFA E20o1E-o1\#1987/78\#4657*.

111 Due to the upheavals in Portugal following the coup d'état in April 1974, the treaty would not be signed until September 1974: "Botschaft des Bundesrates an die Bundesversammlung über ein Doppelbesteuerungsabkommen mit Portugal (vom 23. Oktober 1974)” Bundesblatt 2:46 (1974), pp. 1066-1092, pp. 1066-1067; Georges-André Chevallaz, Federal Councillor and head of the F DF, proposal to the Federal Council, "Double imposition avec le Portugal et la Belgique", 12.02.1974, p. 4, attached to the decree of the Federal Council, "Double imposition avec le Portugal et la Belgique. Signature de la convention par the Chef du département politique", 04.03.1974, dodis.ch/37677.

112 Jean Jacques Maeder, Trade Division, memorandum, "Coopération économique entre la Suisse et le Portugal. 14 novembre 1973, 10h15: Séance préparatoire à la visite officielle que le Ministre Vaz Pinto fera le 23 novembre à M. le Conseil fédéral Brugger", 16.11.1973, SFA E7110\#1984/70\#837* ; Maeder, draft minutes of the working meeting of Friday, 23 november 1973, "Coopération économique entre la Suisse et le Portugal”, 28.11.1973, ibid.

113 Miguel Bandeira Jerónimo, António Costa Pinto, "A Modernizing Empire? Politics, Culture, and Economy in Portuguese Late Colonialism", in Jerónimo, Pinto, The Ends of European Colonial Empires, pp. 51-8o, pp. 62-63. See also Clarence-Smith, Third Portuguese Empire, p. 204. 
general, Swiss investments in Angola and Mozambique increased in the 196os. Nevertheless, few Swiss companies were established in the colonies. Most firms conducted their business through branch offices and subsidiaries in Lisbon. Examples are ввс, Sulzer, and hydroelectric company Conrad Zschokke, which participated in the construction and equipping of dams and energy generating plants in the colonies. Ciba-Geigy and food company Nestlé had sales offices in Angola and Mozambique, although they also conducted part of their business through subsidiaries in South Africa and the Congo, respectively. ${ }^{114}$

In the 196os and 1970s, electrical engineering company ввс repeatedly obtained supply contracts in Angola and Mozambique, notably for thermal power stations II and III in Lourenço Marques (1959-1961 and 1967-1970). ${ }^{115}$ These and many other plants in the Portuguese colonies were built and controlled by SONEFE, a part-public company based in Lisbon that was largely dependent on the Portuguese state. The involvement of the Portuguese government meant that the Swiss Trade Division was favourably disposed towards ввC's March 1967 demand for an ERG cover amounting to CHF 12 million for deliveries destined for thermal power station III in Lourenço Marques. The possible damage to ввС's reputation if it did not receive the contract was considered more important than the risks associated with Mozambique's insecure political future. ${ }^{116}$ ВвС Baden also made deliveries for the construction of the Cabora Bassa dam in Mozambique. ${ }^{117}$

Two Swiss plantations in Mozambique were among the most important in the country. The Companhia de Boror in Macuse, founded in the 189os, grew coconut palms and sisal, kept cattle and produced salt. In the 1930s, Swiss shareholders obtained a majority interest in the plantation. With a turnover of CHF 63 million, the Boror group was the tenth largest company in Mozambique in the early 1970 s and employed tens of thousands of workers. ${ }^{118}$ The

114 Centre d'investigation sur le colonialisme portugais (CISCOP) in collaboration with the Centre Europe-Tiers Monde (CEтiм), Suisse-Portugal. De l'Europe à l'Afrique, Geneva: Editions CETIM, 1973, pp. 77, 98-100.

115 T.-V. Huber, ввс Baden, Aide-mémoire, "Activités MAGUE - Brown Boveri au Portugal dans le domaine des centrales thermiques", 31.10.1973, pp. 1-2, attached to the letter to the Trade Division, "Portugal", 31.10.1973, SFA E7110\#1984/70\#847".

116 Note from Ernst Henri Léchot, responsible for relations with Portugal within the Trade Division, to Hans Bühler, "Mozambique - Kraftwerkbau in Lourenço Marques; GA 7.49, ввс, Baden; 12 Mio Fr." 18.03.1967, SFA E7110\#1978|50\#1682*; Clarence-Smith, Third Portuguese Empire, p. 17 o.

117 See chapter 3 .

118 Georges E. Mourgue d'Algue, Boror, memorandum, "Note à l'intention du département politique, à Berne. Concerne: Companhia do Boror, siège à Macuse/Mozambique. Boror Comercial, siège à Lourenço Marques/Mozambique", o1.10.1974, p. 1, attached to the note from Georges E. Mourgue d'Algue, Comptoir de Représentations d'Etreprises Commerciales 
fifteenth largest company at that time, the Companhia de Culturas de Angoche (CCA), had a turnover of CHF 47 million in the early 1970s. Initially, the company mainly produced sisal and opened a cashew factory in the 196os. In 1974, the Compagnie Commerciale et Agricole S.A. in Glarus, Switzerland, held 97.5\% of the companies' share capital. ${ }^{119}$ Boror and CCA employed Swiss citizens as engineers, technicians, agronomists, and accountants. Smaller retail businesses like Bridler \& Co, Abegg Pharma, Beira Trading Co. Ltd, and City Stores Ltd in Beira were sales agents for important Swiss brands in Mozambique. ${ }^{120}$ By comparison, Swiss interests in Angola during the independence war were less visible. There were few Swiss commercial agencies, as most companies conducted their business through subsidiaries in Lisbon. ${ }^{121}$ On the whole, Swiss economic activities in the colonies were little affected by the independence wars. ${ }^{122}$

Details of Switzerland's overall financial role in the Portuguese colonies and the credit offered by Swiss banks are hard to come by. Part of the difficulty lies in the fact that Swiss credit left few traces in public archives. Only credit arrangements exceeding $\mathrm{CHF} 10$ million or with a term of more than 12 months were subject to the veto of the SNB, which usually also submitted such cases to the federal authorities. ${ }^{123}$ Consequently, the number of credit arrangements mentioned below is almost certainly underestimated. Additionally, some credit granted to institutions in Portugal was used for investment in the colonies. In 1969, a Swiss group led by Lavoro Bank AG, Zurich, subscribed approximately CHF 21.9 million to a bond of CHF 120.8 million of the state-

et Diverses, to Michael Gelzer, deputy chief of the DPA, "Companhia do Boror S.A. Boror Comecial S.A. - Mozambique”, o1.10.1974, SFA E2001E-o1\#1987/78\#4182*; cIscop, SuissePortugal, p. 75; Linder, Die Schweizer in Mosambik, pp. 49-54. The ciscop study published in September 1973 indicates the turnover of the CCA of escudos 442 million without mentioning the year of reference. This amount has been converted to CHF using the average exchange rates between January 1970 and August 1973 (escudos $100=$ CHF 14.3): Data Portal of the SNB, Interest Rates, Yields and Foreign Exchange Market, Historical Exchange Rates of Selected Euro Member Countries, https://data.snb.ch/en/topics/ziredev\#!/cube/ devkuhism (13 January 2021).

119 Memorandum by CCA in preparation of a meeting with the DPA on 3 October 1974, "Companhia de Culturas de Angoche (CCA) S.A.R.L. Antonio Enes", no date, SFA E2001E-01\#1987/78\#4182*; CISCop, Suisse-Portugal, p. 75; Linder, Die Schweizer in Mozambique, pp. 103-109. For the conversion of cCA's turnover of escudos 330 million into Swiss francs, see the preceeding footnote.

120 Jean Pierre Adrien Bertrand, Swiss consul in Mozambique, to the AD, "Mon voyage de service dans le nord de la province du Mozambique du 26 mai au 29 juin 1969", 10.07.1969, p. 2, SFA E2001E\#1980/83\#3788*; Linder, Die Schweizer in Mozambique, pp. 133-150.

121 Letter from René Naville to Pierre Micheli, 16.o8.1968, p. 14, SFA E2001E\#1980/83\#3788*.

122 Letter from the Swiss consul in Mozambique, Jakob Etter, to the DPA, 24.04.1968, p. 2, SFA E2001E\#1980/83\#3788*.

Bott, La Suisse et l'Afrique du Sud, p. 106. 
owned Companhia Mineira do Lobito, a major iron exporter in Angola. ${ }^{124}$ In the early 1970s, five Swiss credit arrangements issued to clients in the Portuguese colonies can be identified, worth a total of CHF 46 million. The issuing institutions were all smaller banks, such as the Swiss group Alpina Investments AG, Xelor Invest AG in Baden, and the Geneva branch of First National City Bank. ${ }^{125}$ The majority of these funds went to Mozambique. The Instituto de Crédito de Moçambique (Mozambican Credit Institute, ICM), founded by the Portuguese government in 1969 to centralise public funds for credit and finance operations for the development of the colony, was partly responsible for this. In the first half of 1972, its administrator, António de Almeida, met with sBA President Alfred Sarasin in Basel. Although there is no record of this meeting, the ICM was very satisfied with the results, as one of its leaders wrote to Sarasin in July 1972: "The contacts you so kindly suggested to us were of great value and interest and we are very pleased to let you know that we already openned [sic] accounts with several renown swiss [sic] banks and are negotiating our first external operations."126

124 CISCOP, Suisse-Portugal, p. 79. The amounts indicated in escudos (escudos 145 million of a bond of escudos 800 million) have been converted to CHF using the average exchange rates for 1970 (escudos $100=\mathrm{CHF} 15.1$ million), the first year that these exchange rates are available on the website of the SNB: Data Portal of the SNB, Interest Rates, Yields and Foreign Exchange Market, Historical Exchange Rates of Selected Euro Member Countries, https://data.snb.ch/en/topics/ziredev\#!/cube/devkuhism (13 January 2021).

125 In 1971, the Swiss financial authorities authorised a credit of US\$ 3.5 million from the First National City Bank, Geneva, to the Sociedade Technica de Equipamentos Industriais \& Agricolas Lda., in Mozambique, this sum was increased by a further US\$ 2 million in 1974. In 1972, Alpina Investment AG granted a first credit of CHF 25 million to the ICM, and a second of Deutschmark 12.5 million to SONEFE in Lourenço Marques. Finally, a credit of Deutschmark 4.95 million from Xelor Invest AG, Baden, to the Instituto dos Cereais de Moçambique was authorised in 1974. The sums have been converted to CHF using the exchange rates indicated in table O.22a of the Hsso database, "Wechselkurse für Sichtdevisen in der Schweiz 1875-1907 und 1913-1992 (in Franken)”. Letter from Nello Celio to the SNB, "Kapitalexport", 30.08.1971, SFA E20o1E-o1\#1991/17_Bd. 986, C.41. Moz.152.o; letter from Leutwiler, Lademann, SNB, to the First National City Bank, Geneva, "Kredit an die Firma Sociedade Tecnica de Equipamentos Indistriais e Agricolas, Lda, Lourenço Marques. Erhöhung von US\$ 2'оoo'ooo.-- auf 5'500'000.--", 04.01.1974, attached to the letter from the SNB to the FDF, the FPD, and the FDEA, "Bewilligung von Kapitalexportgeschäften sowie Kotierungen ausländischer Wertpapiere - Schreiben EFD vom 16.8.1968", ibid.; FP, "Moçambique recebe um crédito de 170 mil contos", Jornal o Seculo, 24.05.1972, SFA E2200.54-03\#1984/100\#172*; letter from Louis Chaney to the Financial and Economic Service of the FPD, 29.08.1972, SFA E2200.54-O3\#1984/100\#172*; letter from Georges-André Chevallaz to the SNB, "Kapitalexport", 18.05.1974, SFA E2001E-o1\#1991/17_ Bd. 986, C.41.Moz.152.o.

126 Letter from Domingos Guimarães Teixeira, chairman of the ICM, to the SBA, attention to Alfred Sarasin, 18.07.1972, Archives of the Swiss Bankers Association, Basel, Switzerland 
Analysis of Switzerland's economic and financial relations in sub-Saharan Africa raises two final questions: that of Switzerland's role and responsibility during the independence wars in Angola and Mozambique; and that of the weight of economic considerations on Swiss foreign policymaking in subSaharan Africa. With regard to the first question, political scientist Sérgio Inácio Chichava argued that, through their economic activities, Swiss citizens contributed to the stabilisation of the Portuguese empire and the exploitation of the Mozambican population. ${ }^{127}$ Swiss trade with and investment in Portugal and its two largest African colonies increased after the two European states joined EFTA in 196o. It accelerated in the late 196os and early 1970s and was not visibly slowed by the independence wars. The conflicts had no direct economic benefits for Switzerland, such as an increase in Swiss arms sales. Nevertheless, Swiss business circles benefited from the economic boom in the colonies that resulted in part from reforms introduced by the colonial authorities as a response to the outbreak of armed violence. In addition, Switzerland's growing economic presence in Angola and Mozambique increased the risks associated with a transfer of power in the colonies. For these reasons, it must be concluded that from a business point of view, there was little incentive for Switzerland's political and economic elites to advocate a change in the colonies' status quo.

The Swiss government was keen to separate political and economic affairs. It refused to accept the view, frequently advanced by Afro-Asian leaders and Swiss civil society actors from the late 196os onwards, that tolerating the economic and financial activities of Swiss citizens and companies in Angola and Mozambique implied official support for Portuguese colonialism. During the independence wars, the leaders of the FPD and the FDEA never spoke out against economic relations with Portugal and its colonies. In some cases, the Swiss state promoted exports to Portuguese Africa by granting an ERG cover. However, it must be stated that the Swiss state's commitments in the two colonies were very small. On 1 January 1972, they amounted to CHF 10 million, more or less evenly distributed, which constituted 3.1\% of all ERG's in Africa and $0.27 \%$ worldwide. ${ }^{128}$ There is only one known case where the FPD's Secretary General expressed his reservations about a credit arrangement issued to the Portuguese colonies. Referring to the harsh criticism by the UNGA and

(ASBA), folder L. 182 Afrique 5.1.71 au 14.7.75. See also the letter from António de Almeida, ICM, to the SBA, 10.04.1972, ibid.

128 ERGs granted to Angola and Mozambique amounted to CHF 4.77 million and CHF 5.22 million, respectively: FDAE, memorandum, "Engagements de la Confédération dans le domaine des garanties contre les risques à l'exportation et de l'investissement en faveur des Etats africains", [January 1972], dodis.ch/36377. 
independent African states of Western financial cooperation with the white minority regimes in Southern Africa, he expressed doubt as to whether the authorisation of a CHF 19.8 million credit arrangement issued by the Zurich branch of Dow Banking Corporation to SONEFE in Angola would be in Switzerland's interest, especially as the issuing institution was foreign-owned. ${ }^{129}$ Due to Portugal's need to develop its economy and attract foreign investment, Swiss-Portuguese economic relations were unequal. Therefore, Swiss delegations could have used their leverage in economic negotiations to express a wish for the decolonisation of Angola and Mozambique. There is no sign that they ever did so.

The second question refers to the role of economic interests in Swiss foreign policymaking in Southern Africa and the Horn. As Somalia's and Ethiopia's poverty limited trade and investments, economic interests were not a driving force of Swiss foreign policy in the Horn of Africa. In Angola and Mozambique, the situation was slightly different. Although Switzerland had more substantial trade with and investments in the Portuguese colonies, the overall importance of Portugal and its colonies to the Swiss economy remained small. Economic considerations are not sufficient to explain why the Swiss government privileged the status quo and relations with Portugal over those with Angola's and Mozambique's potential future rulers. Economic and financial relations with South Africa and, to a lesser extent, with Rhodesia were of paramount importance for Swiss foreign policy in Southern Africa and on the whole African continent. The Swiss government was hesitant to take any steps that might have limited Swiss business in South Africa. It refused to cut its links with the Portuguese colonial power out of fear that it might then be forced to adopt similar measures with regard to the other white minority regimes in the region. At the same time, Switzerland's economic role in South Africa and Rhodesia became a political handicap in the late 1960s, as condemnation of Apartheid and white minority rule was one of the main issues that united independent African governments of all political couleurs. On the whole, Somalia, Ethiopia, Mozambique, and Angola were minor economic and development cooperation partners for Switzerland. For the Swiss government, these countries mattered mainly because of the armed conflicts and regime changes that placed them at the centre of the global East-West and North-South confrontations.

129 Letter from Ernesto Thalmann, Secretary General of the FPD and head of the DPA, to the SNB, "Exportation de capitaux à destination de l'Angola", 16.08.1972, p. 1, SFA E2001E-o1\#1987/78\#4656*. The credit does not seem to have been authorised: Letter from Pierre André Nussbaumer, chief of the Financial and Economic Service of the FPD, to the Office of the Permanent Observer of Switzerland to the United Nations, "Résolution no 2979 (XXVII) du 14.12.1972 / Investissements étrangers en Angola", 16.01.1973, SFA E2001E-o1\#1987/78\#4656*. 